\title{
Bacteria and Host Interplay in Staphylococcus aureus Septic Arthritis and Sepsis
}

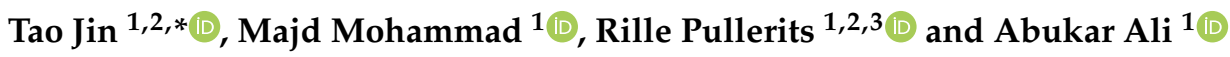 \\ 1 Department of Rheumatology and Inflammation Research, Institute of Medicine, Sahlgrenska Academy, \\ University of Gothenburg, 41346 Gothenburg, Sweden; majd.mohammad@rheuma.gu.se (M.M.); \\ rille.pullerits@rheuma.gu.se (R.P.); abukar.ahmed.ali@rheuma.gu.se (A.A.) \\ 2 Department of Rheumatology, Sahlgrenska University Hospital, 41345 Gothenburg, Sweden \\ 3 Department of Clinical Immunology and Transfusion Medicine, Sahlgrenska University Hospital, \\ 41345 Gothenburg, Sweden \\ * Correspondence: tao.jin@rheuma.gu.se
}

Citation: Jin, T.; Mohammad, M.; Pullerits, R.; Ali, A. Bacteria and Host Interplay in Staphylococcus aureus Septic Arthritis and Sepsis. Pathogens 2021, 10, 158. https://doi.org/ $10.3390 /$ pathogens 10020158

Academic Editors: Seav-ly Tran, Priscilla Branchu, Grégory Jubelin and Nicolas Personnic

Received: 30 December 2020

Accepted: 30 January 2021

Published: 3 February 2021

Publisher's Note: MDPI stays neutra with regard to jurisdictional claims in published maps and institutional affiliations.

Copyright: (c) 2021 by the authors. Licensee MDPI, Basel, Switzerland. This article is an open access article distributed under the terms and conditions of the Creative Commons Attribution (CC BY) license (https:// creativecommons.org/licenses/by/ $4.0 /)$.

\begin{abstract}
Staphylococcus aureus (S. aureus) infections are a major healthcare challenge and new treatment alternatives are needed. S. aureus septic arthritis, a debilitating joint disease, causes permanent joint dysfunction in almost $50 \%$ of the patients. S. aureus bacteremia is associated with higher mortalities than bacteremia caused by most other microbes and can develop to severe sepsis and death. The key to new therapies is understanding the interplay between bacterial virulence factors and host immune response, which decides the disease outcome. S. aureus produces numerous virulence factors that facilitate bacterial dissemination, invasion into joint cavity, and cause septic arthritis. Monocytes, activated by several components of $S$. aureus such as lipoproteins, are responsible for bone destructions. In S. aureus sepsis, cytokine storm induced by S. aureus components leads to the hyperinflammatory status, DIC, multiple organ failure, and later death. The immune suppressive therapies at the very early time point might be protective. However, the timing of treatment is crucial, as late treatment may aggravate the immune paralysis and lead to uncontrolled infection and death.
\end{abstract}

Keywords: Staphylococcus aureus; septic arthritis; sepsis; virulence factors; immunity

\section{S. aureus and Its Virulence Factors}

Nearly half of the human population is at some point colonized by Staphylococcus aureus (S. aureus). Of these, $20 \%$ are persistently colonized while around $30 \%$ are intermittently colonized, mostly in the anterior nares and the skin [1]. However, one should not make the mistake of assuming that $S$. aureus is a harmless microbe that is only part of the normal flora. Rather, $S$. aureus is indeed a very virulent bacteria that causes a wide range of diseases, from simple wound infections and food poisoning to life-threatening conditions such as sepsis, meningitis, and endocarditis [2]. In this review, we focus on septic arthritis and sepsis, which are two of the many severe infections caused by $S$. aureus.

$S$. aureus is a very resilient pathogen due to the various virulence factors it contains and produces, some of which are described below and illustrated in Figure 1. The biological function of $S$. aureus virulence factors and their roles in infections are summarized in Table 1, reviewed in [3].

\subsection{Cell Wall Components}

S. aureus expresses a capsular polysaccharide (CP) that functions as a virulent factor, enabling the bacteria to evade phagocytosis [4]. Several serotypes of the CP have been identified and of those, CP5 and CP8 are the major ones. Most of the clinical isolates of S. aureus have the capability to produce either CP5 or CP8 [4]. S. aureus strains expressing the CP5 capsule significantly increase mortality and arthritis frequency and severity in S. aureus induced sepsis and septic arthritis, respectively, compared to the strains lacking 
the $\mathrm{CP} 5$ capsule [5]. This can be due to the downregulatory effects of $\mathrm{CP} 5$ on the uptake and intracellular killing ability of the phagocytes [5]. The CP8 serotype seems to be less virulent than the CP5 serotype as demonstrated by the ability of CP5 to cause higher bacteremia than the CP8 serotype in a mouse model of bacteremia. The CP5 producing strain also exhibited greater resistance to in vitro opsonophagocytic killing by neutrophils compared to the CP8 serotype [6].

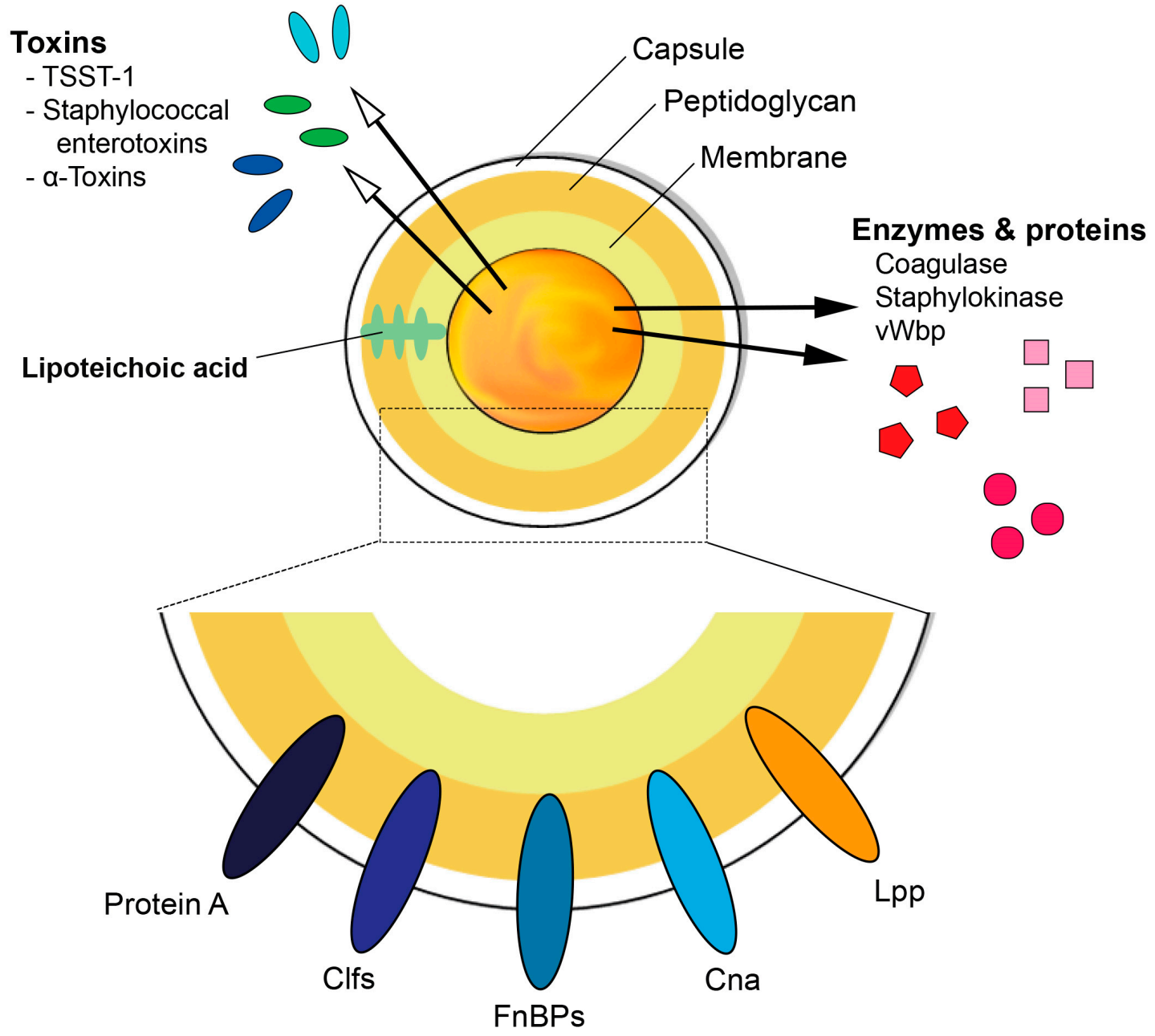

Figure 1. Schematic diagram illustrating the basic structure of Staphylococcus aureus and its ability to express various virulence factors. TSST-1 = Toxic shock syndrome toxin-1, Clfs = clumping factors, FnBPs = fibronectin binding proteins, Cna $=$ Collagen adhesin, $\mathrm{Lpp}=$ lipoproteins, $\mathrm{vWbp}=$ von Willebrand factor-binding protein.

The cell wall of $S$. aureus is made up of a 20-30 nm thick layer of peptidoglycan (PGN). Apart from being a protective barrier of the bacteria, PGN has other functions such as being a scaffold, whereby surface proteins that are fundamental for bacterial virulence can attach [7]. The major structural features of PGN consist of linear glycan strands made up of alternating $\mathrm{N}$-acetylglucosamine and $\mathrm{N}$-acetylmuramic acid residues that are linked by $\beta-1-4$ bonds [8]. The glycan strands are cross-linked by short peptides made up of D-alanine, L-lysine, D-glutamic acid, and L-alanine [9]. The $\varepsilon$-amino groups L-lysine of nearby peptides are cross-linked to D-alanine of other peptides through pentaglycine bridges, thus giving rise to the 3-dimensional structure of the PGN [10]. Due to the critical role it plays in maintaining bacterial structure, growth, and viability, PGN is a target for antibiotics and for the immune system. Nod-like receptors (NLRs), mannose-binding lectin, and lysozyme are some of the components of the immune system that can recognize and target PGN [11]. PGN is a strong inducer of inflammation and stimulates the release of proinflammatory cytokines such as tumor necrosis factor alpha (TNF- $\alpha$ ), interleukin 
(IL)-1 $\beta$, and IL-6. Furthermore, studies have shown that PGN alone can induce arthritis in mice [12] and repetitive inhalation of PGN components can lead to bone loss [13]. However, compared to an extremely potent effect of $S$. aureus lipoproteins (Lpps) the proinflammatory capacity of PGN is mild and transient [14].

Besides, secondary modifications of the PGN cell wall are of vital importance in order to resist host immune response enforcements [15]. Antibacterial enzymes produced by the host, such as lysozyme, also known as muramidase, can cleave PGN in the $\beta-1,4$ linkage site localized between the sugar residues of $\mathrm{N}$-acetylglucosamine and $\mathrm{N}$-acetylmuramic acid, thereby inhibiting bacterial overgrowth [15]. However, S. aureus impressively protects itself from "cell wall breakdowns" by utilizing $O$-acetylation modifications mediated by the O-acetyltransferase A (OatA) enzyme in the PGN cell wall [16]. We demonstrated that the virulence associated with PGN OatA, in both systemic and local S. aureus-induced septic arthritis model, led to milder progression of the disease in mice infected with a $\triangle$ oat $A$ mutant strain [17], indicating the pathogenic importance of the $O$-acetylation of PGN in staphylococcal septic arthritis.

Among the constituents of the cell wall of S. aureus are the teichoic acids, made up of polyribitol and polyglycerol phosphates and sugar-containing polymers [18,19]. Teichoic acids are not unique to $S$. aureus but are found in various Gram-positive bacteria. They can be categorized into wall teichoic acids (WTAs) that are covalently attached to the bacterial PGN, and lipoteichoic acids (LTAs) that are anchored to the lipid membrane through a glycolipid [18,19]. Historically, LTA has been regarded as a potent stimulator of the innate immunity upon its recognition by Toll like receptor 2 (TLR2) among others, leading to the activation of the macrophages and the release of proinflammatory cytokines $[20,21]$. However, recent studies cast a shadow of doubt on these results, pointing a finger to contamination by S. aureus Lpps.

S. aureus Lpp consists of a lipid-moiety and a protein-moiety. The lipid portion is covalently attached to a cysteine residue in the $\mathrm{N}$-terminal region, ultimately facilitating its anchoring in the outer leaflet of the bacterial cytoplasmic membrane [22]. Lpp in $S$. aureus plays an essential role in enabling the bacteria to acquire sufficient loads of iron under infectious conditions. As free iron ions are limited in the host environment and the iron supply is of critical importance for the survival of the staphylococcal pathogen $[23,24]$, inhibition of the Lpp function, through incomplete Lpp maturation, can be deleterious to the metabolic fitness of the bacterium, consequently prompting it to cease in the battle against the host. The lipid structures of Lpp in S. aureus are known as microbe-associated molecular patterns (MAMPs) [22], being vital activators of the innate immunity as they play a potent role in alerting TLR2 in host cells [25].

S. aureus Lpp behave differently in different murine models, depending on the route of infection, the organ of interest, and the assessed time points. In a local knee arthritis model, $S$. aureus Lpps mediated severe arthritogenic and bone destructive effects in NMRI and C57BL/ 6 wild-type mice, but not in TLR2 deficient mice after intra-articular knee joint challenge with the purified Lpp. The arthritogenic properties were mediated through the lipid-moiety [14]. Interestingly, S. aureus SA113 $\Delta l g t$ mutant strain that lacks Lpp maturation, induced more knee swelling compared to its parental strain. This coincided with increased IL-6 expression and higher bacterial burden in the local knee [14]. In contrast, in a hematogenous septic arthritis model, increased bacterial persistence was observed in both C57BL/ 6 wild-type and TLR2 deficient murine kidneys when inoculated intravenously with the $S$. aureus Newman parental strain compared to its $\Delta l g t$ mutant strain [26]. This is in agreement with earlier reports showing that different organs, including the kidneys, exhibited higher bacterial loads when infected with SA113 parental strain in comparison to the $\Delta l g t$ mutant strain, independent of TLR2 and MyD88 signaling [27]. In addition, USA300 MRSA parental strain led to higher bacterial burden in kidneys of Balb/c mice compared to its $\Delta l p l$ mutant strain, lacking the lpl gene cluster [28]. 
Table 1. S. aureus virulence factors and their roles in infections.

\begin{tabular}{|c|c|c|}
\hline & Biological Functions & Role in Infection \\
\hline \multicolumn{3}{|l|}{ Cell Wall Components: } \\
\hline Capsular Polysaccharide & Antiphagocytic [4] & Septic arthritis, sepsis [5] \\
\hline Peptidoglycan & Release of TNF- $\alpha$, IL-6 [12] & Arthritis [12], bone loss [13] \\
\hline Lipoproteins & Activation of innate immunity [25] & Arthritis [14], sepsis [27] \\
\hline \multicolumn{3}{|c|}{ a } \\
\hline & \multirow{2}{*}{$\begin{array}{l}\text { Inhibit complement-mediated phagocytosis }[29,30] \\
\text { Inhibit opsonophagocytosis, B-cell superantigen }\end{array}$} & Septic arthritis, sepsis [31] \\
\hline SpA & & Septic arthritis, sepsis [33] \\
\hline FnBPs & Adhesion and invasion of cells [29] & Biofilm formation [29], sepsis [34] \\
\hline Cna & Mediates binding of S. aureus to cartilage [35] & Septic arthritis [36] \\
\hline $\begin{array}{l}\text { Secreted Proteins: } \\
\text { vWbp }\end{array}$ & Promote blood-clotting [37] & Septic arthritis [38] \\
\hline Eap & Adhesin $[39,40]$ & Inhibit wound healing, biofilm formation $[39,40]$ \\
\hline Staphylokinase & Mediates digestion of fibrin clots [41] & S. aureus skin infections [41] \\
\hline $\begin{array}{l}\text { loxins: } \\
\text { TSST-1 }\end{array}$ & Superantigen [42] & Toxic shock syndrome [43], septic arthritis [44] \\
\hline SE & Superantigen [42] & Toxic shock syndrome [45], food poisoning [46] \\
\hline SEls & Superantigen [42] & Food poisoning [46] \\
\hline$\alpha$ - and $\gamma$-toxins & Cell lysis [47] & Septic arthritis [48] \\
\hline PVL & Cell lysis [47] & Necrotizing pneumonia [49] \\
\hline PSMs & Cell lysis [47], induce inflammation [50] & Biofilm formation [50-52], osteomyelitis [53] \\
\hline Bacterial DNA & Release of TNF- $\alpha$, IL- 6 , IFN- $\gamma$ [54] & Arthritis [55], septic shock [56] \\
\hline
\end{tabular}

Abbreviations: ClfA = Clumping factor A; SpA = Staphylococcal protein A; FnBPs = Fibronectin binding proteins; Cna = Collagen adhesion; $\mathrm{vWbp}$ = von Willebrand factor binding protein; Eap = extracellular adherence protein; TSST-1 = Toxic shock syndrome toxin 1; SE = Staphylococcal enterotoxins; SEls = Staphylococcal enterotoxin like toxins; PVL = Panton-Valentine leucocidin; PSMs = Phenol soluble modulins.

\subsection{Surface Proteins}

S. aureus expresses several surface proteins that play a crucial role in enabling the bacteria to adhere to the host cells, aid in invasion of the bacteria, and evade the immune response mounted by the host [29]. Adherence of bacterial products to host tissues is one of the important steps in initiation of colonization and infections [57]. S. aureus surface proteins usually recognize and adhere to several components of the extracellular matrix (ECM) such as fibronectin, fibrin, and collagen [57].

Microbial surface components recognizing adhesive matrix molecules (MSCRAMMs) are $S$. aureus surface proteins that are anchored on the cell wall PGN. Most MSCRAMMs contain a carboxyl-terminal sorting signal containing LPXTG motif that is cleaved by S. aureus sortase enzymes before being covalently anchored to the cell wall PGN [58]. Notable members of this group include fibronectin binding protein A and B (FnBPA and FnBPB), collagen adhesin (Cna), staphylococcal protein A (SpA), and clumping factor A and $B$ (ClfA and ClfB) [29].

ClfA binds to soluble fibrinogen and has been shown to inhibit complement-mediated phagocytosis $[29,30]$. In S. aureus induced septic arthritis and sepsis, ClfA is an important virulence factor that promotes the pathogenesis of the diseases and can be a target for generation of vaccine against $S$. aureus infections. Passive immunization of mice with rat and rabbit anti-ClfA antibodies gave protection against $S$. aureus induced septic arthritis and sepsis [31].

SpA not only evades the innate immunity by inhibiting opsonophagocytosis, but also has the ability to alter the response of the adoptive immunity by binding to both Fc region of IgG and Fab regions of the B-cell receptor, thereby inducing apoptosis by functioning as a B-cell superantigen [32]. SpA can also diminish the proinflammatory signaling of TNF- $\alpha$ by binding to its receptor, tumor necrosis factor receptor 1 (TNFR1) [59].

FnBPs are important in helping the bacteria to adhere to and invade cells of the host and together with ClfB and SpA play a role, although not yet fully understood, in forming S. aureus biofilms [29]. FnBPs are also involved in the pathogenesis of S. aureus induced sepsis [34].

Cna binds to collagen and helps to mediate the binding of S. aureus to cartilage [35] and was shown by Patti et al. to be involved in the pathogenesis of $S$. aureus septic arthritis [36]. Mice injected with $S$. aureus lacking Cna developed significantly less frequent signs of clinical arthritis (27\%) compared with mice infected with wild type S. aureus (70\%) [36]. 
S. aureus also secretes other proteins that, although not covalently attached to the cell wall PGN, are still surface-associated proteins and act as adhesins-they are commonly known as secreted expanded repertoire adhesive molecules (SERAMs). Coagulase (Coa), von Willebrand factor binding protein (vWbp), extracellular fibrinogen binding protein and extracellular adherence protein (Eap) are several examples of SERAMs [60]. The ability of $S$. aureus to clot human blood is mediated by the direct binding of Coa and vWbp with the hosts' prothrombin. The resulting staphylothrombin complex will eventually convert fibrinogen to fibrin, thus forming fibrin clots [37]. Additionally, as its name suggests, $\mathrm{vWbp}$ acts as a bridge between the bacterial cell wall and von Willebrand factor (vWf) therefore enabling adhesion of $S$. aureus to vascular tissues [61,62]. Intriguingly, vWbp but not Coa expressed by $S$. aureus facilitates the initiation of septic arthritis and such an effect might be mediated through its interaction with a host factor (von Willebrand factor), strongly suggesting bacterial adherence to blood vessels is more important than fibrin clotting function of coagulases in induction of septic arthritis [38]. Eap plays multiple roles in $S$. aureus infections such as acting as an adhesin, inhibiting wound healing and being involved in biofilm formation $[39,40]$.

\subsection{Secreted Proteins}

S. aureus superantigen like proteins (SSLs) are another group of proteins secreted by $S$. aureus that have similar structures as superantigens but lack superantigenic activities. Several SSLs have been identified that are able to interfere with the innate immune response [40,63]. Of these, SSL3 can bind to TLR2 and inhibit the production of TNF- $\alpha$ by macrophages stimulated by heat-killed S. aureus or PGN $[40,63]$.

$S$. aureus also secretes numerous other proteins such as the chemotaxis inhibitory protein of $S$. aureus, staphylococcal complement inhibitor, and formyl peptide receptor-like1 inhibitory protein that aid the bacteria to evade opsonization and phagocytosis [2].

Enzymes secreted by $S$. aureus include catalase, proteases, hyaluronidase, lipases, nucleases, and staphylokinase. Apart from exploiting host tissues and converting them into nutrients for the bacteria, $S$. aureus enzymes also facilitate invasion and evasion of the immune system [2]. Hyaluronidase breaks down hyaluronic acid that holds the cells of the body together, thus facilitating the invasion of S. aureus further into tissues [64]. Staphylokinase, which mediates the digestion of fibrin clots via activation of plasminogen to plasmin, has been shown to promote the establishment of $S$. aureus skin infections, but at the same time decrease the severity of the disease [41]. Intriguingly, fibrinolysis activated by staphylokinase prevents biofilm formation and promotes detachment of biofilms [65].

\subsection{Toxins}

The secretion of toxins is another virulence weapon of $S$. aureus that bacteria use to manipulate and gain the upper hand against the immune system. S. aureus secretes large amounts of toxins with several different virulence factors. Several toxins secreted by $S$. aureus have superantigenic properties, i.e., the ability to cause non-specific activation of T-cells, leading to massive polyclonal $\mathrm{T}$ cell activation followed by a vast release of cytokines with subsequent fever, shock, and multiple organ failure $[66,67]$. It was long assumed that superantigens bind only to the $\mathrm{T}$ cell receptor (TCR) on the T-cells and major histocompatibility complex (MHC) class II molecules on antigen presenting cells (APCs) [68]. However, it has since emerged that superantigens can also bind to CD28, thus forming a more stable complex than previously thought [69].

Toxic shock syndrome toxin 1 (TSST-1), staphylococcal enterotoxins (SEs) (AE, G-1, $\mathrm{R}$ and $\mathrm{T}$ ), and staphylococcal enterotoxin like toxins (SEls) (J-Q, S, U, V, and X) are all superantigenic toxins produced by $S$. aureus [42]. Of the SEs, SEB and SEC are known to cause non-menstrual toxic shock syndrome (TSS) [45]. Furthermore, SEs have long been known to cause food poisoning whereas SEls were thought not to have emetic properties. However, recent studies have found that some newly discovered SEls (I-Q) have emetic properties and may also play some role in staphylococcal food poisoning [46]. TSST-1 
accounts for almost half of all non-menstrual TSS in the general population and almost all cases of menstruation associated TSS [43]. In addition, clonal expansion of CD4+ V $\beta 11+\mathrm{T}$ cells induced by $S$. aureus producing TSST-1 toxin has been shown to be involved in the pathogenesis of $S$. aureus septic arthritis [44].

Another set of toxins secreted by $S$. aureus includes the hemolysins (also known as alpha $(\alpha)$, beta $(\beta)$, and gamma $(\gamma)$ toxins), cytolytic peptides (phenol soluble modulins (PSMs)) and bi-component leukocidins (including Panton-Valentine leukocidin (PVL)). All are characterized by their ability to cause cell lysis by forming pores in the cell membrane [47].

The first to be discovered and most studied of the hemolysins is the $\alpha$-toxin, with an ability to form pores and lyse a broad range of cell types such as peripheral blood monocytes, platelets, and keratinocytes, and cells of the endothelium [70]. In addition to $\alpha$ toxins, $\gamma$ toxins produced by $S$. aureus are also a critical virulence factor in $S$. aureus induced septic arthritis since mice injected with a mutant lacking both $\alpha$ and $\gamma$ toxins showed significantly less frequent and less severe arthritis compared to wild-type strains producing both $\alpha$ and $\gamma$ toxins [48].

As mentioned, PVL has adhesion properties, damages leukocytes and has also been implicated in the pathogenesis of necrotizing pneumonia [49].

The PSMs consist of small peptides and similar to the hemolysins and leukocidins have pore-forming properties. The PSMs can target several cell types such as erythrocytes and leukocytes and have been shown to induce inflammation [50]. Members of this family include the PSM-mec, PSM $\alpha$ 1-4, PSM $\beta$ 1-2, and PSM $\gamma$ [50]. Apart from the role in biofilm structuring and dispersal [50-52], PSMs facilitate invasion and killing of osteoblasts thereby aggravating $S$. aureus-induced osteomyelitis [53]. PSMs are largely produced by community-associated methicillin-resistant S. aureus (CA-MRSA). Furthermore, they are involved in biofilm formation and are known to cause aggressive S. aureus infections [52].

\subsection{Bacterial DNA}

Bacterial but not mammalian DNA can induce inflammatory response. The proinflammatory properties of bacterial DNA are largely dependent on bacterial CpG motifs that are unmethylated cytosine-phosphate-guanine $(\mathrm{CpG})$ dinucleotides. The $\mathrm{CpG}$ motifs are predominantly prevalent only in bacterial DNA, but not in mammalian DNA [71]. $S$. aureus DNA can induce the production of proinflammatory cytokines such as TNF- $\alpha$, IL-6, and interferon-gamma (IFN- $\gamma$ ) via TLR9 [54]. Indeed, the injection of S. aureus DNA in mice led to rapid activation of macrophages followed by massive release of TNF- $\alpha$ that triggered lethal shock in mice [56]. Furthermore, previous results showed that $S$. aureus DNA containing CpG motifs induced arthritis [55] and meningitis through NF- $\mathrm{B}$ [72]. However, our recent data suggest that DNA from antibiotic-killed $S$. aureus plays a minor role in mediating arthritis [73].

\section{The Immune Response during $S$. aureus Infections}

S. aureus, through its vast virulence factors, seeks multiple ways to colonize and establish infections in humans. However, upon intrusion, this pathogenic bacterium highly alerts the host's immune system. Consequently, a battle between the host and the pathogen starts. The role of different immune cells in S. aureus septic arthritis and sepsis is summarized in Table 2. 
Table 2. The role of different immune cells in S. aureus septic arthritis and sepsis.

\begin{tabular}{cccc}
\hline Cell Types & Septic Arthritis & Bacterial Clearance & Sepsis \\
\hline Neutrophils & Protective [74] & Enhance [74] & Pathogenic [74] \\
Monocytes/macrophages & Pathogenic [75] & Enhance [75] & Protective [75] \\
NK cells & Protective [76] & Enhance [76] & Type 2 ILCs are protective [77] \\
Innate lymphoid cells & NA & NA & Pathogenic [78] \\
CD4+ T cells & Pathogenic [78] & No effect [78] & NA \\
CD8 T cells & NA & NA & NA \\
Regulatory T cells & Protective [79] & No effect [79] & NA \\
Th17 T cells & NA & NA & No effect [80] \\
B cells & No effect [80] & NA & Protective? [80] \\
Thrombocytes & NA & NA & Protective [81] \\
Eosinophils & NA & NA & Protective [82] \\
Basophils & NA &
\end{tabular}

$\mathrm{NA}=$ not assessed; ILCs $=$ innate lymphoid cells.

\subsection{Innate Immunity}

The host's innate immune system immediately executes a series of protective measures against intruding pathogens, such as S. aureus, and this serves as the first line of defense [83]. This action is initially implemented through recognition via pattern recognition receptors (PRRs) that distinctively sense pathogenic components and promptly trigger the activation of innate immune cells [83]. Among these immune cells are the phagocytes.

\subsection{Neutrophils}

Neutrophils are the most abundant type of white blood cells (WBCs) in the body, constituting around $50-70 \%$ of all WBCs and play a very important role in the innate immunity. During S. aureus infections, neutrophils are quickly recruited from the blood and migrate to the infection site via a process known as chemotaxis [84]. Neutrophils have several PRRs, such as Toll like receptors (TLRs) that can recognize different conserved molecules from microbes, so called pathogen-associated molecular patterns (PAMPs). At the infection site, PRRs on the neutrophils will recognize PAMPs from bacteria, which is subsequently internalized. Around the internalized bacteria, a cellular compartment known as phagosome will be formed, which fuses with lysosomes to form phagolysosomes. The rapid release of reactive oxygen species through oxidative burst, antibacterial peptides that have microbicidal effects, proteinases that degrade bacterial components, and proteins that sequester essential bacterial nutrients are some of the mechanisms employed by the neutrophils in the phagolysosomes to neutralize the internalized bacteria [85].

Neutrophils also possess the ability to kill bacteria extracellularly by releasing its contents and DNA, known as neutrophil extracellular traps (NETs). This process involves forming a web-like structure interconnected with histones and containing antimicrobial agents such as defensins and myeloperoxidase that trap the bacteria and eliminate it [86]. Neutrophils are killing machines that do an excellent job phagocytizing bacteria and thus have a short life span (1-2 days) as a regulatory precaution to avoid tissue damage. Neutrophils are absolutely essential in protecting the host against live S. aureus infections, as clearly exhibited by the significantly higher mortality and more severe arthritis caused by $S$. aureus in neutrophil-depleted mice compared to wild-type controls [74]. In addition, in the murine S. aureus skin infection model, Mölne et al. demonstrated that neutrophil depletion worsens the disease severity with increased bacterial burden in the skin tissue [87]. On the other hand, the depletion of neutrophils did not have any impact in arthritis caused either by antibiotic-killed S. aureus or S. aureus Lpp [14,73].

\subsection{Macrophages}

Macrophages are outstanding phagocytes that not only eliminate $S$. aureus but also function as APCs and are involved in activating the adaptive immunity in case of serious 
breaches. Activated macrophages are also potent secretors of the proinflammatory cytokine TNF- $\alpha$, whose role in S. aureus infections will be described later.

Two distinct subtypes of macrophages have been described with opposing activities: M1 macrophages and M2 macrophages. M1 macrophages, also known as "classically activated" macrophages, are proinflammatory. The enzyme nitric oxide synthase (iNOS) is expressed by M1 macrophages and helps convert arginine into nitric oxide (NO), which inhibits proliferation of infected cells [88,89]. Microbial products, such as lipopolysaccharides (LPS) or the proinflammatory cytokine IFN- $\gamma$, stimulate the M1 macrophages phenotype that will result in a Th1 immune response [90]. This will lead to the production of more proinflammatory cytokines such as IL-12, TNF- $\alpha$, and IFN- $\gamma$ in a positive feedback loop, thus maintaining the M1 macrophage phenotype. M2 macrophages, or "alternatively activated macrophages", are anti-inflammatory and give rise to a Th2 immune response and thus promote cell proliferation and wound repair. The anti-inflammatory cytokine IL-4 promotes the differentiation of macrophages into M2 macrophages and stimulates the production of IL-10, which further enhances the phenotype of M2 macrophages [91].

Macrophages have specific names depending on the tissue on which they reside. For example, Kupffer cells are macrophages that are found in the liver, whereas microglia, adipose tissue macrophages, and osteoclasts are found in the central nervous system, adipose tissue, and bones, respectively [92]. Osteoclasts and osteoblasts play an important role in maintaining bone homeostasis by degrading and synthesizing bones, respectively [93]. IL-15, a proinflammatory pleiotropic cytokine, plays a potent role in early osteoclast differentiation [94]. Additionally, the receptor activator of nuclear factor kappa-B-ligand (RANKL)-dependent osteoclastogenesis is known to be impaired in the mice lacking the IL-15 receptor [95]. In S. aureus septic arthritis, mice lacking IL-15 were found to have a reduced number of osteoclasts in their joints, which also coincided with reduced arthritis severity and less joint destruction compared to wild-type mice [96]. Activation of osteoclasts requires the RANKL, a member of the tumor necrosis factor (TNF) superfamily that is found on the surface of osteoblasts, to bind to receptor activator of nuclear factor kappa-B (RANK) on the surface of osteoclasts. RANKL has been implicated in S. aureus infections, and its inhibition reduces bone loss in S. aureus septic arthritis [97].

Macrophages have been shown to play dual roles in S. aureus infections. On the one hand, Verdrengh et al. showed that macrophages are involved in aggravating S. aureus arthritis and the deficiency of macrophages attenuated the disease [75]. On the other hand, the ability of the host to clear invading bacteria in the kidneys is impeded, thus leading to higher mortality [75]. Further studies also showed that macrophages are involved in arthritis triggered by bacterial DNA containing CpG motifs [98]. We recently demonstrated that purified S. aureus Lpp rapidly initiates the recruitment of monocytes/macrophages and neutrophils upon local knee injection [14]. In the model of local knee arthritis induced by purified S. aureus Lpp, depletion of monocytes/macrophages resulted in diminished bone destruction [14]. This demonstrates that monocytes/macrophages are the key cell types in the development of local knee arthritis induced by purified Lpp. Similarly, double depletion of both neutrophils and monocytes abrogated the arthritis induced by antibiotickilled S. aureus [73].

\subsection{Natural Killer (NK) Cells}

NK cells are a type of white blood cells that play an important role in the innate immune system. NK cells respond to and eliminate virus-infected and tumor cells and do not require antibodies or MHC to respond to these cells. NK cells play a protective role during S. aureus infections $[76,99]$. The depletion of NK cells in mice before inoculation with a TSST-1 secreting strain of $S$. aureus is associated with higher susceptibility to develop S. aureus septic arthritis as compared to control mice with intact NK cells [76]. Further studies have also shown that mice depleted of NK cells are significantly more susceptible to pulmonary S. aureus infections compared to wild-type mice [99], underscoring the protective role of NK cells against $S$. aureus infections. 


\subsection{The Complement System}

The complement system serves as the first line of defense and is a crucial part of the innate immune system. It is made up of several plasma proteins and can be activated through three different pathways: the classical, the alternative and the lectin pathway. Whenever bacteria are successful in breaching the physical barriers, the complement system, regardless of the activation pathway, will recognize this and form enzyme complexes known as $\mathrm{C} 3$ convertases whose task is to cleave the complement component 3 (C3) into two different proteins. The $\mathrm{C} 3 \mathrm{a}$, a proinflammatory anaphylatoxin, helps with the recruitment of the phagocytes to the infection site, whereas the $\mathrm{C} 3 \mathrm{~b}$ opsonizes the invading S. aureus, thus making it easier to be phagocytosed [100].

Apart from opsonizing the bacteria, the complement system can also form a lytic complex known as the membrane attack complex (MAC) on the surface of invading bacterial cells that will lead to the lysis and eventual death of the microbe. However, the MAC recognizes only Gram-negative bacteria and thus S. aureus is spared from the potent killing ability of the MAC mechanism [101].

The complement system is imperative to the host defense during S. aureus infection as its deficiency renders the host defenseless and significantly increases the susceptibility to S. aureus infections [102]. Recent data from our lab show that mice lacking the complement component 3 (C3-/-) are highly susceptible to S. aureus septic arthritis. Kidney abscess formation and bacterial burden in the kidneys are also negatively affected in the C3-/- mice compared to the wild type controls with functioning complement system [103]. The results underscore the importance of the complement system in fending off $S$. aureus infections.

\subsection{Adaptive Immunity}

\subsubsection{T-Cells}

T-cells or T-lymphocytes are an integral part of adaptive immunity. They originate in the bone marrow but mature in the thymus, hence the name T-cells. T-cells are recognized from other lymphocytes due to their unique TCR displayed on the cell surface.

T-helper ( $\mathrm{T}_{\mathrm{h}}$ ) cells (CD4 ${ }^{+} \mathrm{T}$-cells) express $\mathrm{CD} 4$ glycoprotein on their surface, recognize antigens presented by MHC class II and secrete cytokines that are necessary for both the cell-mediated and humoral immune response [104]. Cytotoxic T-cells (CD8 ${ }^{+} \mathrm{T}-$-cells) express CD8 glycoproteins, recognize antigens presented by MHC class I and eliminate virus-infected and tumor cells [104]. Regulatory T-cells (Tregs) play an important role in maintaining balance by preventing the immune response to self-antigens and suppressing excessive immune response that can cause autoimmune diseases [105]. T-helper 17 (Th17) cells are a unique $\mathrm{CD} 4^{+}$T-cell subset characterized by the production of IL-17 that is a highly inflammatory cytokine playing an important role in the pathogenesis of several autoimmune diseases [106].

$\mathrm{CD}^{+}$T-cells differentiate into two major subgroups: Th1 and Th2 cells. Th1 cells mainly secrete the cytokines IFN- $\gamma$ and IL-2, respond to intracellular microbes and stimulate phagocyte mediated uptake and elimination of microbes [107,108]. Th2 cells usually respond to extracellular pathogens such as gastrointestinal parasites, secrete mainly IL-4 and IL-5 cytokines and promote eosinophil activation and phagocyte-independent immune response [107]. Cytotoxic T-lymphocyte-associated protein 4 (CTLA4), a naturally occurring protein receptor expressed on the surface of the T-cells, has the ability to inhibit the activation of the T-cell by competitively binding to CD80/86. CTLA4-Ig, a biologic that inhibits the full activation of T-cells, downregulates the Th2 response, and has little effect on Th1 response [109]. Septic arthritis mice pretreated with CTLA4-Ig exhibited more severe joint inflammation but lower levels of IL-4 compared to the control mice [110]. Although both $\mathrm{CD}^{+}$and $\mathrm{CD} 8^{+} \mathrm{T}$ cells are found in the inflamed synovium, $\mathrm{CD} 4^{+} \mathrm{T}$ cells make up the overwhelming part. Furthermore, depletion of $\mathrm{CD} 4^{+}$cells significantly ameliorates the course of septic arthritis in mice, whereas depletion of $\mathrm{CD} 8^{+} \mathrm{T}$ cells does not alter the course of arthritis compared to control mice [78]. Thus, it appears that $\mathrm{CD} 4^{+} \mathrm{T}$ cells are pathogenic during $S$. aureus septic arthritis due to their ability to produce proinflammatory 
cytokines such as TNF- $\alpha$ and IFN- $\gamma$ via activated macrophages [78]. Recent results also found that $\mathrm{CD}^{+} \mathrm{T}$ cells promote the pathogenesis of $S$. aureus pneumonia and Pseudomonas aeruginosa septic arthritis [111,112].

The depletion of Tregs by anti-CD25 monoclonal antibodies aggravated the severity of septic arthritis without impact on bacterial clearance in mice [79], suggesting the protective role of Tregs in development of septic arthritis. The role of Th17 cells in S. aureus septic arthritis and sepsis is still unclear. However, IL-17 produced by Th17 cells is crucial for host defense against $S$. aureus skin infections [113] and septic arthritis [114].

\subsubsection{Natural Killer T (NKT) Cells}

NKT cells are a unique subset of T cells that can have features of both T cells and NK cells. While other subsets of $\mathrm{T}$ cells recognize protein antigens, NKT cells are unique in that they recognize lipids and glycolipids and make up a tiny percentage of blood T cells. Studies from S. aureus triggered sepsis indicate that NKT cells do not play any significant role in the course of the disease [115].

\subsubsection{B-Cells}

Unlike T-cells, B-cells do not seem to be the driving force behind the pathogenesis of $S$. aureus infections. Studies from murine $S$. aureus septic arthritis model showed that B-cell deficient mice do not differ from the wild-type controls with regards to arthritis and clearance of the bacteria, but tended to have higher mortality [80].

\subsubsection{Other Cell Types}

Innate lymphoid cells (ILCs) are enriched at barrier surfaces of hosts and play critical roles in maintaining tissue homeostasis and immune defense. ILCs are divided to three groups of cells with distinct immunological functions [116]. Recently, activation of type 2 ILCs (ILC2s) were shown to be protective against $S$. aureus sepsis in mice by promoting eosinophilia, enhancement of type 2 immunity, and consequent balance of dysregulated septic inflammatory responses [77].

Basophils are the rarest granulocyte ( $<1 \%$ of peripheral blood leukocytes). A very recent study demonstrated that basophil-deficient mice exhibited reduced bacterial clearance and increased mortality in a cecal ligation and puncture model of sepsis and such effect was due to reduced basophil-derived TNF production [82]. So far, the role of basophils in S. aureus septic arthritis and sepsis is still largely unknown.

Thrombocytes are the major effector cell in hemostasis. Interestingly, they also contribute to the protection against $S$. aureus infections through direct bacterial killing effect and by enhancing phagocytic capacity of macrophages [117]. Not surprisingly, thrombocyte depletion gave rise to reduced bacterial clearance and increased mortality in S. aureus systemic infections [81].

\subsubsection{Cytokines}

Several cytokines are secreted by cells of both the innate and the adaptive immunity and have different roles in S. aureus infections. Some of them will briefly be discussed below and are listed in Table 3. 
Table 3. The role of cytokines in S. aureus septic arthritis and sepsis.

\begin{tabular}{|c|c|c|c|}
\hline Cytokine & Cell Source & Function & Role in S. aureus Infections \\
\hline TNF- $\alpha$ & $\begin{array}{l}\text { Macrophages } \\
\text { T-cells }\end{array}$ & Proinflammatory & $\begin{array}{l}\text { Aggravate S. aureus induced septic arthritis but } \\
\text { protective in sepsis [118]. }\end{array}$ \\
\hline IL-1 & $\begin{array}{l}\text { Macrophages } \\
\text { Dendritic cells } \\
\text { Endothelial cells }\end{array}$ & Proinflammatory & $\begin{array}{l}\text { Protective in S. aureus induced septic } \\
\text { arthritis and sepsis [119]. }\end{array}$ \\
\hline IL-6 & Macrophages and T cells & Proinflammatory & $\begin{array}{c}\text { Elevated IL-6 levels in synovial fluid from septic } \\
\text { arthritis patients [120]. The role of IL-6 was not yet } \\
\text { assessed in animal models for septic arthritis } \\
\text { and sepsis. }\end{array}$ \\
\hline IL-12 & $\begin{array}{l}\text { Monocytes } \\
\text { Macrophages } \\
\text { Dendritic cells }\end{array}$ & Proinflammatory & $\begin{array}{l}\text { Protective in S. aureus induced sepsis but not } \\
\text { septic arthritis [121] }\end{array}$ \\
\hline IL-4 & Th2 cells & Anti-inflammatory & $\begin{array}{l}\text { Dual role in S. aureus induced septic arthritis and } \\
\text { sepsis depending on the genetic background of the } \\
\text { host }[122,123] .\end{array}$ \\
\hline IL-10 & $\begin{array}{l}\text { Monocytes } \\
\text { Dendritic cells } \\
\text { T-cells }\end{array}$ & Anti-inflammatory & Protective in S. aureus induced septic arthritis [124]. \\
\hline IL-17 & Th17 cells & Proinflammatory & $\begin{array}{c}\text { Protective in local but not systemic S. aureus } \\
\text { infection [114]. }\end{array}$ \\
\hline IFN- $\gamma$ & $\begin{array}{l}\text { NK cells } \\
\text { T-cells }\end{array}$ & Proinflammatory & $\begin{array}{l}\text { Protective in S. aureus induced sepsis but aggravates } \\
\text { septic arthritis [125]. }\end{array}$ \\
\hline Janus kinase & All cells & Proinflammatory & $\begin{array}{l}\text { Protective in S. aureus septic arthritis but pathogenic } \\
\text { in sepsis [126] }\end{array}$ \\
\hline
\end{tabular}

TNF- $\alpha$, one of the most studied cytokines due to its role in inflammation and many diseases, is involved in the acute-phase reaction and is mainly secreted by activated macrophages and CD4+ cells, neutrophils, mast cells, and NK cells [127].

TNF- $\alpha$ has a contrasting role during $S$. aureus infections. In patients with $S$. aureus arthritis, the levels of TNF- $\alpha$ have been shown to be highly elevated in the synovial fluid. Furthermore, it has been suggested that the levels of the cytokine could function as a predictor in determining the prognosis of the disease, with higher levels associated with worse prognosis [128]. Animal studies have shown that TNF/lymphotoxin (LT)- $\alpha$ double knockout mice have significantly less severe $S$. aureus arthritis compared to the wild-type mice [118]. Indeed, we could also show that TNFR1 knockout mice exhibited less arthritis compared to wild-type mice in antibiotic-killed S. aureus induced arthritis [73]. Anti-TNF treatment was also able to abrogate arthritis induced by antibiotic-killed S. aureus [73]. Additionally, in the S. aureus skin infection model, mice pretreated with anti-TNF agent exhibited smaller lesion (abscess) sizes compared to the control PBS-treated mice [129]. On the other hand, the lack of TNF- $\alpha$ was associated with impaired ability of the host to successfully clear invading S. aureus in the kidneys [110,118], thus leading to increased mortality [118].

IL-1 cytokine family is a group of eleven cytokines that play an important role in the inflammatory response. Of these, most is known regarding IL- $1 \alpha$ IL- $1 \beta$, and IL-1 receptor antagonist (IL-1Ra). IL-1 $\alpha$ plays a central role in the induction of fever, sepsis, and inflammation and is produced by activated macrophages, neutrophils, and endothelial and epithelial cells. IL-1 $\beta$ is predominantly produced by activated macrophages as a proprotein and is cleaved by caspase 1 into its active mature form [130]. It plays an important role in pain, inflammation, and cartilage degradation in several inflammatory diseases [131]. In $S$. aureus systemic infections, IL-1R signaling is also essential to the host protection against the bacteria as shown by Hultgren et al. IL- $1 \mathrm{R}^{-} /^{-}$mice inoculated with S. aureus developed 
significantly higher S. aureus septic arthritis and sepsis compared to wild-type IL-1R ${ }^{+}{ }^{+}$ mice [119].

IFN- $\gamma$, a potent proinflammatory cytokine, is mainly produced by NK cells and T-cells. Apart from inhibiting viral and even bacterial infections, IFN- $\gamma$ activates and stimulates the macrophages to better phagocytose intracellular invaders. Different roles of IFN- $\gamma$ in $S$. aureus triggered sepsis and septic arthritis have been described. Mice deficient of the IFN- $\gamma$ receptor develop significantly more severe and frequent arthritis [132]. The mortality levels due to sepsis are also significantly increased during the early stages of the infection in the mice lacking IFN- $\gamma$ receptor, whereas in later stages the reverse is true with higher mortality levels in the wild-type mice [132]. Likewise, in vivo administration of IFN- $\gamma$ before and after inoculation of $S$. aureus improved the survival of the mice while at the same time increased the severity and frequency of arthritis [125]. The positive effects on mortality due to in vivo administration of IFN- $\gamma$ correlated with improved phagocytosis and better clearance of the bacteria in both, the liver and the kidneys. On the other hand, treatment of the mice with anti-IFN- $\gamma$ monoclonal antibodies attenuated the severity and frequency of arthritis due to lower levels of serum TNF- $\alpha$, IL-6, and IL-1 $\beta$ [125].

IL-4 is an anti-inflammatory cytokine that has a role in differentiation of naïve T-cells into Th2 cells and the differentiation of B-cells into plasma cells. IL-4 promotes the cytotoxic activity of CD8+ cells, decreases the production of IFN- $\gamma$ by T-cells and NK cells, and affects monocytes/macrophages by reducing their production of proinflammatory cytokines like IL-1, IL-6, and TNF- $\alpha$ [133]. IL-4 inhibits the intracellular killing of $S$. aureus in infected macrophages, without affecting phagocytosis and provides therefore a favorable milieu for survival of staphylococci [122]. In S. aureus infections, the dual role of IL-4 has been described depending on the genetic background of the host. In inbred C57BL/ 6 mice, IL-4 was shown to be a driving force of septic arthritis and sepsis by significantly impairing the capability of the host to clear the bacteria [122]. Enhanced staphylococcal clearance from joints and kidneys, reduced mortality, and decreased frequency of arthritis was observed in IL-4 deficient C57BL/ 6 mice. However, in another inbred strain, 129SV mice, the opposite was true, i.e., IL-4 protected the mice from S. aureus induced sepsis [123]. IL-4 deficient $129 \mathrm{SV}$ mice had a thousand times higher bacterial growth in their kidneys, significantly elevated mortality, and delayed development of septic arthritis. A differential pattern of host responsiveness was seen between these mouse strains and explanation for the discrepant outcome could lie in the variation in circulating IL-4 levels-serum IL-4 was not detectable in C57BL/ 6 mice whereas increased IL-4 production was observed in 129SV mice in response to $S$. aureus infection [123].

Although IL-6 has been shown to have some anti-inflammatory features, it is usually regarded as a proinflammatory cytokine [134]. Macrophages and T cells mainly produce IL6 during infections or trauma. In S. aureus infections, IL-6 is usually elevated together with other proinflammatory cytokines such as IL-1 $\beta$ and TNF- $\alpha$ [128]. Synovial IL- 6 together with synovial lactate and synovial fluid white blood cells count have been touted as good parameters for diagnosing septic arthritis [120].

IL-10 is an anti-inflammatory cytokine produced mainly by monocytes and to a smaller extent the lymphocytes. IL-10 promotes Th2 response while downregulating Th1 cytokine secretion by macrophages and monocytes. IL-10 plays a crucial role protecting the host against $S$. aureus septic arthritis by promoting bacterial clearance [124].

IL-12 is primarily produced by monocytes, macrophages, and dendritic cells. Apart from stimulating the differentiation of naive T-cells to Th1 cells, IL-12 is also involved in the production of IFN- $\gamma$ and TNF- $\alpha$ via T-cells and NK-cells. In S. aureus infections, IL-12 is crucial for the survival of the host and deficiency of IL-12 is associated with significant accumulation of S. aureus in many organs leading ultimately to the demise of the host [121].

IL-17A is a proinflammatory cytokine produced by activated Th17 subset of T-cells. IL-17A plays a significant role in host defense against local S. aureus infections due to its ability to induce chemokines that attract and recruit neutrophils [135]. Thus, in local $S$. aureus infection, IL-17A-/- mice developed more synovitis and erosions and more weight 
loss compared to the wild-type mice [114]. On the other hand, IL-17A-/- mice did not differ from wild-type mice regarding the severity and the frequency of arthritis induced by antibiotic-killed S. aureus [73].

\section{Septic Arthritis and Sepsis}

Septic arthritis is a rapidly progressing and devastating joint disease caused by pathogen infection. S. aureus accounts for about $70 \%$ of the septic arthritis cases and has been shown to cause more severe infection than other microbes $[136,137]$. Prevalence of septic arthritis is around 6 cases per 100,000 in the general population and much higher in rheumatoid arthritis (RA) patients approaching about 70 cases per 100,000 [137]. The mortality rate is around $10-15 \%$ in non-RA patients with monoarthritis, i.e., arthritis in a single joint. Polyarthritis, on the other hand, is associated with much worse prognosis, with the mortality rate ranging up to $30-50 \%[137,138]$. Risk factors for septic arthritis include: increasing age, pre-existing joint diseases (especially RA), intravenous drug abuse, prosthetic joints, and diabetes mellitus $[137,138]$. Treatment of septic arthritis consists primarily of antibiotics and joint aspiration to flush out the intra-articular pus containing both bacteria and infiltrating immune cells $[139,140]$. One of the devastating aspects of septic arthritis is that despite optimal antibiotic treatment, almost half of the patients will develop irreversible joint destruction [138]. Definitive diagnosis of septic arthritis requires the isolation of the microbe from the synovial fluid, although due to the fast progressing nature of the disease, physicians do not and should not wait for culture results before initiating treatment with broad spectrum antibiotics [139].

Hematogenous spread of $S$. aureus to the synovial membrane of joints is the most commonly reported route of acquiring septic arthritis, although the bacteria can also be introduced directly into the joints by trauma (e.g., needle accident) or spread from neighboring inflamed tissues [140]. In a retrospective study, more than $70 \%$ of septic arthritis cases were shown to be caused by hematogenous spreading [141]. The probability to develop septic arthritis following bacteremia with the optimal arthritogenic dose of S. aureus in our animal model can reach up to $80-90 \%$. In patients, the frequency of the bone and joint infections after S. aureus bacteremia varies from 12 to $17 \%$ in different studies [142,143]. Once inside, the bacteria will employ different virulence factors to attach to the host tissue and proliferate while the host immune system will respond to the invading bacteria. It has been shown that the destruction of joints in S. aureus septic arthritis is not only caused by the invading microbes, but also by cells and molecules of the immune system, involving both the innate and adaptive immunity [140].

Sepsis is defined as the systemic inflammatory response due to an infection and is usually caused by bacteria such as S. aureus, Pseudomonas aeruginosa, and Escherichia coli [144]. S. aureus bacteremia is associated with higher mortalities than bacteremia caused by most other microbes and can develop to sepsis and severe sepsis [144]. Despite advances made in critical care and treatment, sepsis remains one of the foremost causes of death in critically ill patients. Mortality in sepsis is around $10-20 \%$ and increases significantly up to $80 \%$ if a septic shock develops $[145,146]$.

The pathogenesis of $S$. aureus sepsis is multifactorial and is mediated by components of the bacteria and the exaggerated immune response mounted by the host. Bacterial superantigens can cause non-specific activation of T-cells leading to massive polyclonal $\mathrm{T}$ cell activation and resulting in a vast release of proinflammatory cytokines such as TNF- $\alpha$ and IL-1 $\beta[66,67]$. PGN and LTA, cell wall components of $S$. aureus, can also interact with CD14 molecules through TLR2 and stimulate the release of proinflammatory cytokines (TNF- $\alpha$ and IL-6) and chemokines (IL-8) further potentiating the systemic inflammation in sepsis $[54,147]$. This is followed by a massive release of anti-inflammatory cytokines in response to the inflammation whereby the immune regulation is rendered inactive, leading to a state of immunosuppression [148]. Without a proper functioning immune system, the bacteria have free reign to proliferate and spread to different organs. Coagulation disorder, characterized by an excessive coagulation, is another attribute of sepsis. The 
coagulation cascade can be activated through proinflammatory cytokines such as TNF- $\alpha$, IL-1 $\beta$, and IL-6 leading to disseminated intravascular coagulation (DIC) $[147,149]$. DIC is soon followed by thrombocytopenia, i.e., the lack of platelets in the blood resulting in massive bleeding from several sites and leading to organ failure [149]. Given together, the pathogenesis of sepsis includes systemic inflammation, loss of immune regulation, and excessive coagulation that altogether will lead to multiple organ failure, shock, and finally the demise of the host.

\section{Bacteria and Host Interplay Determines the Disease Outcome}

\subsection{Joint Affinity of S. aureus is the Key Mechanism of Septic Arthritis}

The majority of septic arthritis has the hematogenous origin. The course of the disease can be divided into two stages-early and late. During the early stage, S. aureus needs to adapt to the host environment, to survive the bactericidal components and phagocyte attacks in the blood, to disseminate to synovial tissue, and finally to reach the joint cavity. In the joint cavity (late stage), S. aureus proliferates and releases a vast arsenal of components that arouse a host response and cause joint damage. Bacterial joint invasion is the key step of disease mechanism of septic arthritis, since the initial cause of disease is the invading S. aureus in affected joints. The defect of innate immunity on the host side increases the susceptibility to $S$. aureus septic arthritis, which is correlated to impaired bacterial clearance. Several bacterial factors are known to determine the joint-invading process of $S$. aureus. Actually, so far all of them are bacteria surface proteins including clumping factors, protein A, and Cna. Unlike S. aureus, the related coagulase-negative staphylococci (CoNS) are hardly found in native septic arthritis, suggesting coagulases might play a major role in the disease pathogenesis. Indeed, our very recent data demonstrate that the depletion of $\mathrm{vWbp}$ but not Coa almost fully abolished the capability of $S$. aureus to invade joint cavity but no other organs. Such effect is fully dependent on the vWf expression in the host and strongly suggests that the interaction between $\mathrm{vWbp}$ and $\mathrm{vWf}$ determines joint-specific invasiveness of $S$. aureus [38]. It seems that expression of $S$. aureus surface proteins that "stick to" blood vessel wall or joint/cartilage is the key mechanism of disease initiation.

\subsection{The Impact of Bacteria and Host Interplay on Biofilm Formation in Septic Arthritis}

Biofilm is a type of bacterial growth characterized by formation of multicellular bacterial communities, held together by the extracellular matrix. Environmental bacteria often form biofilms and $65-80 \%$ of infections including osteomyelitis and septic arthritis according to Centres for Disease Control and Prevention (CDC) and National Institutes of Health (NIH) are also characterized by formation of bacterial biofilms [150]. The biofilm-like structure was frequently observed in the cases of joint infections [151]. In vitro, S. aureus aggregation was promoted and extremely thick biofilm was formed in the presence of synovial fluids [152]. Biofilm formation renders the bacteria resistant to treatment with antibiotics, as a diffusion of chemical compounds across the matrix is severely restricted. Furthermore, host defense, such as neutrophils, are unable to phagocytize bacteria in a biofilm [153]. Surface proteins of S. aureus are likely involved in promoting cell-cell adhesion and biofilm formation [150]. On the other hand, PSMs secreted by S. aureus in a quorum-sensing controlled fashion, structure biofilms, and cause biofilm detachment and bacterial dissemination [51]. In infection caused by the presence of foreign implants, the first stage of biofilm formation is the coating of the implant surface by host-derived proteins, such as fibrinogen, fibronectin, and collagen. S. aureus can adhere to these proteins via so called MSCRAMMs [154]. After bacterial attachment, material secreted by the microorganisms, such as DNA and polysaccharide, imbed the bacteria and protect them from environmental stress. Intriguingly, bacteria also utilize the host proteins, e.g., fibrin to build up the biofilm architectures [65,155]. With time, biofilm architecture changes, a process termed biofilm maturation [156]. Importantly, plasmin, the key fibrinolysis molecule abundant in the circulation, can digest most of host-derived adhesions and extracellular matrix proteins. We have recently shown that fibrinolysis activated by both bacterial 
and host plasminogen activators prevent biofilm formation and promote detachment of biofilms $[65,157]$.

\subsection{The Role of Microbiome in Septic Arthritis and Sepsis}

Every human body is colonized by huge number of microorganisms after birth. Microbiome, a diverse community of microorganisms and the environment that they occupy, has been shown to be associated with human diseases, such as metabolic disorders, respiratory diseases, autoimmune diseases, and psychological disorders [158]. Not surprisingly, microbiome also plays a potent role in infectious diseases, as microbiota indirectly mediate colonization resistance by stimulating host mucosal immune defenses to prevent invasion of pathogens and subsequent infection. A very good example is Clostridium difficile ( $C$. difficile) infection that is likely caused by disruption of gut microbiota and increased community susceptibility to the vegetative growth of $C$. difficile spores by antibiotic therapy [159]. At the same time, the changes of microbial community structure alter host responses to induce low levels of inflammation, which leads to greater risk for infections [160]. It is known that vaginal microbiota with low diversity (mostly Lactobacillus species) is associated with a lower risk of bacterial vaginosis and decreased risk of HIV-1 infection compared to highdiversity vaginal microbiota [161]. A very recent study demonstrated that mice fed with western-type diet lost Bacteroidetes in their gut microbiota and become susceptible to lethal postoperative infection associated with multiple drug resistant organisms present among the gut microbiota after exposure to antibiotics and an aseptic surgical procedure [162]. This study clearly demonstrated the dysbiosis as a potential risk factor for sepsis. Indeed, in elderly patients, dysbiosis was shown to be strongly associated with increased incidence of a subsequent hospitalization for sepsis [163]. Additionally, dysbiosis in patients who undergo allogeneic bone marrow transplantation was also associated with increased risk of bloodstream infection and sepsis [164].

So far, it is still largely unknown whether microbiome plays the role in initiation and development of septic arthritis. However, several lines of evidences suggest that the microbiome may contribute to the pathogenesis of autoimmune arthritis such as RA and spondyloarthritis. It has been shown that segmented filamentous bacteria, a single gut-residing microbe, is able to drive autoimmune arthritis via Th17 cells [165]. In mice with collagen induced arthritis, significant dysbiosis and mucosal inflammation occurred at the early stage of the disease. Depletion of the microbiota resulted in decreased disease severity [166]. In patients, dysbiosis with specific characteristics was evidenced in both RA and spondyloarthritis [167]. Secondary osteoarthritis is one of the most common consequences of septic arthritis. Germ-free mice were shown to be more resistant to development of osteoarthritis after joint injury [168], suggesting the potent role of gut microbiota in osteoarthritis pathogenesis. Interestingly, treatment with lyophilized inactivated culture of Bifidobacterium longum protected cartilage structure lesions and decreased type II collagen degradation in a spontaneous model of osteoarthritis [169]. In addition, the prebiotic fiber supplementation displayed the protective effect on osteoarthritis development in the rat model of obesity [170]. As the microbiome plays a role in both autoimmune arthritis and osteoarthritis, it is likely that the microbiome has some impact on the disease pathogenesis of septic arthritis, which should be studied in the future.

\subsection{Exaggerated Immune Response Causes Joint Damage in Septic Arthritis}

As soon as bacteria reach the joint cavity, a rapid immune response is triggered. In patients, even after they have received immediate treatment, the joint damage caused by septic arthritis is often irreversible, leading to permanent joint dysfunction for up to half of the patients [171]. Recently, we demonstrated that antibiotic-killed S. aureus induce destructive arthritis through TNFR1 and that bacterial cell walls are the culprits [73]. Among the $S$. aureus cell wall components, Lpp are TLR2 agonists and the main immune stimulators, while LTA are of much less importance in this respect. Lipidation of Lpp is known to be crucial for virulence in murine $S$. aureus systemic infection [22]. Our recent 
data suggest that $S$. aureus Lpps are one of the main instigators of joint damages in septic arthritis [14].

Focal bone destruction in autoimmune arthritis is due to excess bone resorption by osteoclast activation, which is mediated by increased local expression of RANKL compared to its decoy receptor osteoprotegerin [172]. Osteoclasts not only exist inside the bone, but can also be derived from mature monocytes and macrophages when a suitable microenvironment is provided [173]. Monocytes/macrophages have been shown to mediate bone erosions in the arthritis induced by other $S$. aureus components, such as bacterial DNA [55], PGN [12], and Lpp [14], which suggests that monocytes/macrophages are the most important immune cells in determining the outcome of septic arthritis.

To limit the immune response and reduce the risk of permanent joint destruction, a combination treatment of antibiotics and immunomodulatory therapy was proposed by us $[73,174]$. However, our recent data suggest that there are potential dangers associated with such combination therapies as long as the problem of antibiotic resistance persists $[73,110]$. Interestingly, different immunomodulatory therapies have distinct clinical outcomes. Anti-TNF therapy increased the bacterial load in kidneys but had no impact on septic arthritis development. In contrast, CTLA4-Ig treatment and IL-1 inhibitor aggravated septic arthritis but with no impact on bacteria clearance $[110,175]$.

\subsection{Cytokine Storm and Immune Paralysis in S. aureus Sepsis}

Spread of staphylococci in the body or severe local infection, lead to systemic inflammation. Activated immune cells secrete vast amounts of proinflammatory cytokines, like IL- 6 and TNF- $\alpha$, which is called a "cytokine storm". These further increase the activity of the immune system, which in extreme cases can lead to organ damage, DIC, and death. At the same time, inflammation induces expression of anti-inflammatory cytokines, such as IL-10, which are responsible for regulating the immune response. Elevated levels of both pro- and anti-inflammatory cytokines in circulation reflect severity of infection and inflammation. Already in 1987, the TNF inhibitor was shown to prevent septic shock in lethal bacteremia in baboons [176]. Not surprisingly, direct intravenous injection of TNF and IL-1 synergistically induced a shock-like status in rabbits [177]. Obviously, those proinflammatory cytokines play a potent role in induction of septic shock and lethality. We also demonstrated that the combination therapy of antibiotics and anti-TNF reduces mortality of S. aureus sepsis in mice [174]. Importantly, anti-TNF treatment also prevented S. aureus enterotoxin induced shock [174]. Not only TNF, but also other host mediators are involved in sepsis pathogenesis. A good example is the high mobility group box 1 protein (HMGB-1) as a late mediator for the endotoxin induced lethality [178]. Despite the robust anti-shock effect in the animal model, the clinical trial of anti-TNF treatment was proved to be a big failure [179]. The explanation might be that clinical trials were very heterogeneous in causative pathogens that might lead to differences in the immunological response and different stages of sepsis when the treatments were introduced. Indeed, a recent study demonstrated that RA patients treated with TNF inhibitors survived better in severe infections than those treated with conventional disease-modifying antirheumatic drugs (DMARDs). This suggests that successful immunosuppression at the very early stage of disease might be beneficial [180]. Actually, our very recent data also demonstrated that pretreatment of mice with JAK kinase inhibitor (tofacitinib) significantly prolonged the survival of mice with S. aureus sepsis [126]. More importantly, pretreatment of tofacitinib exerted full protection for $S$. aureus enterotoxin induced shock in mice, whereas later treatment had no effect at all [126]. These clearly show that in the clinical situation, the more personalized drug choice is crucial for better outcome in management of $S$. aureus sepsis.

It is also clear that immune paralysis directly after hyperinflammation in sepsis is another problem regarding the concept of immune suppressive treatment in sepsis [181], as patients with $S$. aureus sepsis may have already passed the hyperinflammatory stage and come in the hypoinflammatory stage. Additionally, the half-time of biologics is often long, which makes the treatment in context of sepsis even more complicated. 


\section{Therapies Targeting Host and Bacteria Interaction}

Currently, three main approaches are used to treat staphylococcal infections [182]. The primary goal is the removal of infecting bacteria by using antibiotics and damaged tissues and inflammatory infiltrates-therefore abscesses are drained, infected joints undergo lavage and, if necessary, a larger scale debridement is performed in soft tissue infections. Finally, a supportive treatment is needed to maintain homeostasis if organ dysfunctions develop during infection. Possibilities of disease prevention are limited to controlling the spread of multiresistant strains, isolation of patients spreading bacteria in hospital environments, and elimination of staphylococcal colonization in high-risk groups by an aggressive chemotherapy [182]. The development of vaccine, especially those focusing on the generation of opsonic antibodies, is a history of repeated failures [183].

The development of new treatments for septic arthritis has stagnated. The current treatment alternatives are exactly the same as those used 30 years ago. To limit the immune response and reduce the risk of permanent joint destruction, a combination treatment of antibiotics and immunomodulatory therapy including non-steroidal anti-inflammatory drug [184,185], corticosteroids [186], and TNF inhibitors [174] has been tested in the animal models. Indeed, in patients two double-blind randomized controlled trials showed a positive effect for the addition of corticosteroids to antibiotics in the treatment of septic arthritis [187]. However, larger randomized controlled trial with long term follow up and safety data is still missing. Therefore, we do not have enough evidence to recommend corticosteroids alongside antibiotics for the treatment of septic arthritis. Actually, there are potential dangers associated with such combination therapies as long as the problem of antibiotic resistance persists $[110,175]$. Dissecting the interaction between bacterial components and host factors responsible for joint inflammation and destruction is the key for the development of new therapies. Our recent data demonstrate that interaction between $\mathrm{vWbp}$ and $\mathrm{vWf}$ mediates the joint-specific invasiveness of S. aureus [38]. We suggest that three distinct strategies might therefore be used in the future studies to block the interaction between $\mathrm{vWf}$ and $\mathrm{vWbp}$ : (a) passive and active immunization against $\mathrm{vWbp}$; (b); cleavage of $\mathrm{vWbp}$ by recombinant ADAMTS 13 (a disintegrin and metalloproteinase with a thrombospondin type 1 motif, member 13); and (c) specially designed peptides interfere with binding site of $\mathrm{vWbp} / \mathrm{vWf}$.

\section{Concluding Remarks}

The interplay between bacteria and host determines the outcome of $S$. aureus septic arthritis. Innate immunity including neutrophils and complement system plays a protective role in the development of septic arthritis. The most reasonable explanation for this is that efficient innate immune killing leads to lower bacterial concentration in the blood stream, which gives less chance to bacterial entry to the joints. In contrast, the role of adaptive immunity in septic arthritis is less clear than innate immunity. On the bacterial side, S. aureus surface proteins mediate the joint invasiveness of bacteria via interaction with the blood vessel surface and joint components, which usually does not cause bacterial overgrowth in organs. As soon as bacteria reach the joint cavity, the bacterial components such as Lpp arouse a strong immune response with rapid recruitment of neutrophils and monocytes. The bone destruction in septic arthritis is closely related to monocyte/macrophage activation and differentiation. The future therapeutic strategies against septic arthritis might be combination therapy of antibiotics and anti-monocyte activation treatment.

In S. aureus sepsis, cytokine storm (highly elevated TNF, IL-1, and IL6) induced by S. aureus superantigens, Lpp, PGN, and other components causes hyperinflammation, DIC, multiple organ failure, and later death. The immune suppressive therapies at the very early time point might be protective. However, the timing of treatment is crucial, as late treatment may aggravate the immune paralysis and lead to uncontrolled infection and death. 
Author Contributions: All authors have contributed substantially to this work. Some content of this article is a part of the Ph.D. thesis of A.A. All authors have read and agreed to the published version of the manuscript.

Funding: This work was supported by the Swedish Medical Research Council (grant number 523-2013-2750 to T.J.); grants from the Swedish state under the agreement between the Swedish Government and the county councils, the ALF-agreement (grant number ALFGBG-823941 to T.J., ALFGBG-926621 to R.P.); Foundations of the Royal Swedish Academy of Sciences [grant number ME2015-0119 to A.A.]; E and K.G. Lennanders Scholarship to [M.M. and A.A.]

Institutional Review Board Statement: Not applicable.

Informed Consent Statement: Not applicable.

Data Availability Statement: Not applicable.

Conflicts of Interest: The authors declare no conflict of interest.

\section{References}

1. Wertheim, H.F.; Melles, D.C.; Vos, M.C.; van Leeuwen, W.; van Belkum, A.; Verbrugh, H.A.; Nouwen, J.L. The role of nasal carriage in Staphylococcus aureus infections. Lancet Infect. Dis. 2005, 5, 751-762. [CrossRef]

2. Bien, J.; Sokolova, O.; Bozko, P. Characterization of Virulence Factors of Staphylococcus aureus: Novel Function of Known Virulence Factors That Are Implicated in Activation of Airway Epithelial Proinflammatory Response. J. Pathog. 2011, 2011, 601905. [CrossRef] [PubMed]

3. Ali, A. Biologics in Staphylococcus Aureus Arthritis. Ph.D. Thesis, University of Gothenburg, Gothenburg, Sweden, 2016.

4. Nanra, J.S.; Buitrago, S.M.; Crawford, S.; Ng, J.; Fink, P.S.; Hawkins, J.; Scully, I.L.; McNeil, L.K.; Aste-Amezaga, J.M.; Cooper, D.; et al. Capsular polysaccharides are an important immune evasion mechanism for Staphylococcus aureus. Hum. Vaccin. Immunother. 2013, 9, 480-487. [CrossRef] [PubMed]

5. Nilsson, I.M.; Lee, J.C.; Bremell, T.; Ryden, C.; Tarkowski, A. The role of staphylococcal polysaccharide microcapsule expression in septicemia and septic arthritis. Infect. Immun. 1997, 65, 4216-4221. [CrossRef]

6. Watts, A.; Ke, D.; Wang, Q.; Pillay, A.; Nicholson-Weller, A.; Lee, J.C. Staphylococcus aureus strains that express serotype 5 or serotype 8 capsular polysaccharides differ in virulence. Infect. Immun. 2005, 73, 3502-3511. [CrossRef]

7. Sharif, S.; Singh, M.; Kim, S.J.; Schaefer, J. Staphylococcus aureus peptidoglycan tertiary structure from carbon-13 spin diffusion. J. Am. Chem. Soc. 2009, 131, 7023-7030. [CrossRef]

8. Vollmer, W.; Blanot, D.; de Pedro, M.A. Peptidoglycan structure and architecture. FEMS Microbiol. Rev. 2008, 32, 149-167. [CrossRef]

9. Willey, J.M.; Sherwood, L.; Woolverton, C.J. Prescott's Microbiology, 9th ed.; McGraw-Hill: New York, NY, USA, $2014 ;$ p. 1.

10. Grundling, A.; Schneewind, O. Cross-linked peptidoglycan mediates lysostaphin binding to the cell wall envelope of Staphylococcus aureus. J. Bacteriol. 2006, 188, 2463-2472. [CrossRef]

11. Kashyap, D.R.; Wang, M.; Liu, L.H.; Boons, G.J.; Gupta, D.; Dziarski, R. Peptidoglycan recognition proteins kill bacteria by activating protein-sensing two-component systems. Nat. Med. 2011, 17, 676-683. [CrossRef]

12. Liu, Z.Q.; Deng, G.M.; Foster, S.; Tarkowski, A. Staphylococcal peptidoglycans induce arthritis. Arthritis Res. Ther. 2001, 3, 375-380. [CrossRef]

13. Dusad, A.; Thiele, G.M.; Klassen, L.W.; Gleason, A.M.; Bauer, C.; Mikuls, T.R.; Duryee, M.J.; West, W.W.; Romberger, D.J.; Poole, J.A. Organic dust, lipopolysaccharide, and peptidoglycan inhalant exposures result in bone loss/disease. Am. J. Respir. Cell Mol. Biol. 2013, 49, 829-836. [CrossRef] [PubMed]

14. Mohammad, M.; Nguyen, M.T.; Engdahl, C.; Na, M.; Jarneborn, A.; Hu, Z.; Karlsson, A.; Pullerits, R.; Ali, A.; Gotz, F.; et al. The YIN and YANG of lipoproteins in developing and preventing infectious arthritis by Staphylococcus aureus. PLoS Pathog. 2019, 15, e1007877. [CrossRef] [PubMed]

15. Bera, A.; Herbert, S.; Jakob, A.; Vollmer, W.; Gotz, F. Why are pathogenic staphylococci so lysozyme resistant? The peptidoglycan O-acetyltransferase OatA is the major determinant for lysozyme resistance of Staphylococcus aureus. Mol. Microbiol. 2005, 55, 778-787. [CrossRef] [PubMed]

16. Sychantha, D.; Jones, C.S.; Little, D.J.; Moynihan, P.J.; Robinson, H.; Galley, N.F.; Roper, D.I.; Dowson, C.G.; Howell, P.L.; Clarke, A.J. In vitro characterization of the antivirulence target of Gram-positive pathogens, peptidoglycan O-acetyltransferase A (OatA). PLoS Pathog. 2017, 13, e1006667. [CrossRef] [PubMed]

17. Baranwal, G.; Mohammad, M.; Jarneborn, A.; Reddy, B.R.; Golla, A.; Chakravarty, S.; Biswas, L.; Gotz, F.; Shankarappa, S.; Jin, T.; et al. Impact of cell wall peptidoglycan O-acetylation on the pathogenesis of Staphylococcus aureus in septic arthritis. Int. J. Med. Microbiol. 2017, 307, 388-397. [CrossRef]

18. Reichmann, N.T.; Grundling, A. Location, synthesis and function of glycolipids and polyglycerolphosphate lipoteichoic acid in Gram-positive bacteria of the phylum Firmicutes. FEMS Microbiol. Lett. 2011, 319, 97-105. [CrossRef] 
19. Brown, S.; Santa Maria, J.P., Jr.; Walker, S. Wall teichoic acids of gram-positive bacteria. Annu. Rev. Microbiol. 2013, 67, 313-336. [CrossRef]

20. Morath, S.; Geyer, A.; Hartung, T. Structure-function relationship of cytokine induction by lipoteichoic acid from Staphylococcus aureus. J. Exp. Med. 2001, 193, 393-397. [CrossRef]

21. Morath, S.; Stadelmaier, A.; Geyer, A.; Schmidt, R.R.; Hartung, T. Synthetic lipoteichoic acid from Staphylococcus aureus is a potent stimulus of cytokine release. J. Exp. Med. 2002, 195, 1635-1640. [CrossRef]

22. Nguyen, M.T.; Gotz, F. Lipoproteins of Gram-Positive Bacteria: Key Players in the Immune Response and Virulence. Microbiol. Mol. Biol. Rev. 2016, 80, 891-903. [CrossRef]

23. Sheldon, J.R.; Heinrichs, D.E. The iron-regulated staphylococcal lipoproteins. Front. Cell. Infect. Microbiol. 2012, 2, 41. [CrossRef] [PubMed]

24. Hammer, N.D.; Skaar, E.P. Molecular mechanisms of Staphylococcus aureus iron acquisition. Annu. Rev. Microbiol. 2011, 65, 129-147. [CrossRef] [PubMed]

25. Nguyen, M.T.; Uebele, J.; Kumari, N.; Nakayama, H.; Peter, L.; Ticha, O.; Woischnig, A.K.; Schmaler, M.; Khanna, N.; Dohmae, N.; et al. Lipid moieties on lipoproteins of commensal and non-commensal staphylococci induce differential immune responses. Nat. Commun. 2017, 8, 2246. [CrossRef] [PubMed]

26. Mohammad, M.; Hu, Z.; Ali, A.; Kopparapu, P.K.; Na, M.; Jarneborn, A.; Stroparo, M.d.N.; Nguyen, M.-T.; Karlsson, A.; Götz, F.; et al. The role of Staphylococcus aureus lipoproteins in hematogenous septic arthritis. Sci. Rep. 2020, 10, 7936. [CrossRef]

27. Schmaler, M.; Jann, N.J.; Ferracin, F.; Landolt, L.Z.; Biswas, L.; Gotz, F.; Landmann, R. Lipoproteins in Staphylococcus aureus mediate inflammation by TLR2 and iron-dependent growth in vivo. J. Immunol. 2009, 182, 7110-7118. [CrossRef]

28. Nguyen, M.T.; Kraft, B.; Yu, W.; Demircioglu, D.D.; Hertlein, T.; Burian, M.; Schmaler, M.; Boller, K.; Bekeredjian-Ding, I.; Ohlsen, K.; et al. The $v$ Sa $\alpha$ Specific Lipoprotein Like Cluster (lpl) of S. aureus USA300 Contributes to Immune Stimulation and Invasion in Human Cells. PLoS Pathog. 2015, 11, e1004984. [CrossRef]

29. Foster, T.J.; Geoghegan, J.A.; Ganesh, V.K.; Hook, M. Adhesion, invasion and evasion: The many functions of the surface proteins of Staphylococcus aureus. Nat. Rev. Microbiol. 2014, 12, 49-62. [CrossRef]

30. Hair, P.S.; Echague, C.G.; Sholl, A.M.; Watkins, J.A.; Geoghegan, J.A.; Foster, T.J.; Cunnion, K.M. Clumping factor A interaction with complement factor I increases C3b cleavage on the bacterial surface of Staphylococcus aureus and decreases complementmediated phagocytosis. Infect. Immun. 2010, 78, 1717-1727. [CrossRef]

31. Josefsson, E.; Hartford, O.; O’Brien, L.; Patti, J.M.; Foster, T. Protection against experimental Staphylococcus aureus arthritis by vaccination with clumping factor A, a novel virulence determinant. J. Infect. Dis. 2001, 184, 1572-1580. [CrossRef]

32. Kobayashi, S.D.; DeLeo, F.R. Staphylococcus aureus protein A promotes immune suppression. MBio 2013, 4, e00764-13. [CrossRef]

33. Palmqvist, N.; Foster, T.; Tarkowski, A.; Josefsson, E. Protein A is a virulence factor in Staphylococcus aureus arthritis and septic death. Microb. Pathog. 2002, 33, 239-249. [CrossRef] [PubMed]

34. Palmqvist, N.; Foster, T.; Fitzgerald, J.R.; Josefsson, E.; Tarkowski, A. Fibronectin-binding proteins and fibrinogen-binding clumping factors play distinct roles in staphylococcal arthritis and systemic inflammation. J. Infect. Dis. 2005, 191, 791-798. [CrossRef] [PubMed]

35. Switalski, L.M.; Patti, J.M.; Butcher, W.; Gristina, A.G.; Speziale, P.; Hook, M. A collagen receptor on Staphylococcus aureus strains isolated from patients with septic arthritis mediates adhesion to cartilage. Mol. Microbiol. 1993, 7, 99-107. [CrossRef] [PubMed]

36. Patti, J.M.; Bremell, T.; Krajewska-Pietrasik, D.; Abdelnour, A.; Tarkowski, A.; Ryden, C.; Hook, M. The Staphylococcus aureus collagen adhesin is a virulence determinant in experimental septic arthritis. Infect. Immun. 1994, 62, 152-161. [CrossRef] [PubMed]

37. Vanassche, T.; Verhaegen, J.; Peetermans, W.E.; van Ryn, J.; Cheng, A.; Schneewind, O.; Hoylaerts, M.F.; Verhamme, P. Inhibition of staphylothrombin by dabigatran reduces Staphylococcus aureus virulence. J. Thromb. Haemost. 2011, 9, 2436-2446. [CrossRef]

38. Na, M.; Hu, Z.; Mohammad, M.; Stroparo, M.D.N.; Ali, A.; Fei, Y.; Jarneborn, A.; Verhamme, P.; Schneewind, O.; Missiakas, D.; et al. The Expression of von Willebrand Factor-Binding Protein Determines Joint-Invading Capacity of Staphylococcus aureus, a Core Mechanism of Septic Arthritis. mBio 2020, 11. [CrossRef] [PubMed]

39. Hammel, M.; Nemecek, D.; Keightley, J.A.; Thomas, G.J., Jr.; Geisbrecht, B.V. The Staphylococcus aureus extracellular adherence protein (Eap) adopts an elongated but structured conformation in solution. Protein Sci. 2007, 16, 2605-2617. [CrossRef]

40. Zecconi, A.; Scali, F. Staphylococcus aureus virulence factors in evasion from innate immune defenses in human and animal diseases. Immunol. Lett. 2013, 150, 12-22. [CrossRef]

41. Kwiecinski, J.; Jacobsson, G.; Karlsson, M.; Zhu, X.; Wang, W.; Bremell, T.; Josefsson, E.; Jin, T. Staphylokinase Promotes the Establishment of Staphylococcus aureus Skin Infections While Decreasing Disease Severity. J. Infect. Dis. 2013, 208, 990-999. [CrossRef]

42. Xu, S.X.; McCormick, J.K. Staphylococcal superantigens in colonization and disease. Front. Cell. Infect. Microbiol. $2012,2,52$. [CrossRef]

43. McCormick, J.K.; Tripp, T.J.; Llera, A.S.; Sundberg, E.J.; Dinges, M.M.; Mariuzza, R.A.; Schlievert, P.M. Functional analysis of the TCR binding domain of toxic shock syndrome toxin-1 predicts further diversity in MHC class II/superantigen/TCR ternary complexes. J. Immunol. 2003, 171, 1385-1392. [CrossRef] [PubMed]

44. Abdelnour, A.; Bremell, T.; Holmdahl, R.; Tarkowski, A. Clonal expansion of T lymphocytes causes arthritis and mortality in mice infected with toxic shock syndrome toxin-1-producing staphylococci. Eur. J. Immunol. 1994, 24, 1161-1166. [CrossRef] [PubMed] 
45. Dinges, M.M.; Orwin, P.M.; Schlievert, P.M. Exotoxins of Staphylococcus aureus. Clin. Microbiol. Rev. 2000, 13, 16-34. [CrossRef] [PubMed]

46. Omoe, K.; Hu, D.L.; Ono, H.K.; Shimizu, S.; Takahashi-Omoe, H.; Nakane, A.; Uchiyama, T.; Shinagawa, K.; Imanishi, K. Emetic potentials of newly identified staphylococcal enterotoxin-like toxins. Infect. Immun. 2013, 81, 3627-3631. [CrossRef] [PubMed]

47. Vandenesch, F.; Lina, G.; Henry, T. Staphylococcus aureus hemolysins, bi-component leukocidins, and cytolytic peptides: A redundant arsenal of membrane-damaging virulence factors? Front. Cell. Infect. Microbiol. 2012, 2, 12. [CrossRef] [PubMed]

48. Nilsson, I.M.; Hartford, O.; Foster, T.; Tarkowski, A. Alpha-toxin and gamma-toxin jointly promote Staphylococcus aureus virulence in murine septic arthritis. Infect. Immun. 1999, 67, 1045-1049. [CrossRef] [PubMed]

49. Diep, B.A.; Chan, L.; Tattevin, P.; Kajikawa, O.; Martin, T.R.; Basuino, L.; Mai, T.T.; Marbach, H.; Braughton, K.R.; Whitney, A.R.; et al. Polymorphonuclear leukocytes mediate Staphylococcus aureus Panton-Valentine leukocidin-induced lung inflammation and injury. Proc. Natl. Acad. Sci. USA 2010, 107, 5587-5592. [CrossRef]

50. Cheung, G.Y.; Joo, H.S.; Chatterjee, S.S.; Otto, M. Phenol-soluble modulins-critical determinants of staphylococcal virulence. FEMS Microbiol. Rev. 2014, 38, 698-719. [CrossRef]

51. Periasamy, S.; Joo, H.S.; Duong, A.C.; Bach, T.H.; Tan, V.Y.; Chatterjee, S.S.; Cheung, G.Y.; Otto, M. How Staphylococcus aureus biofilms develop their characteristic structure. Proc. Natl. Acad. Sci. USA 2012, 109, 1281-1286. [CrossRef]

52. Peschel, A.; Otto, M. Phenol-soluble modulins and staphylococcal infection. Nat. Rev. Microbiol. 2013, 11, 667-673. [CrossRef]

53. Rasigade, J.P.; Trouillet-Assant, S.; Ferry, T.; Diep, B.A.; Sapin, A.; Lhoste, Y.; Ranfaing, J.; Badiou, C.; Benito, Y.; Bes, M.; et al. PSMs of hypervirulent Staphylococcus aureus act as intracellular toxins that kill infected osteoblasts. PLoS ONE 2013, 8, e63176. [CrossRef] [PubMed]

54. Fournier, B.; Philpott, D.J. Recognition of Staphylococcus aureus by the innate immune system. Clin. Microbiol. Rev. 2005, 18, 521-540. [CrossRef] [PubMed]

55. Deng, G.M.; Nilsson, I.M.; Verdrengh, M.; Collins, L.V.; Tarkowski, A. Intra-articularly localized bacterial DNA containing CpG motifs induces arthritis. Nat. Med. 1999, 5, 702-705. [CrossRef] [PubMed]

56. Sparwasser, T.; Miethke, T.; Lipford, G.; Borschert, K.; Hacker, H.; Heeg, K.; Wagner, H. Bacterial DNA causes septic shock. Nature 1997, 386, 336-337. [CrossRef]

57. Joh, D.; Wann, E.R.; Kreikemeyer, B.; Speziale, P.; Hook, M. Role of fibronectin-binding MSCRAMMs in bacterial adherence and entry into mammalian cells. Matrix Biol. 1999, 18, 211-223. [CrossRef]

58. An, Y.H.; Friedman, R.J. Handbook of Bacterial Adhesion Principles, Methods, and Applications; Humana Press: Totowa, NJ, USA, 2000; Volume xvi, 645p.

59. Gomez, M.I.; O'Seaghdha, M.; Magargee, M.; Foster, T.J.; Prince, A.S. Staphylococcus aureus protein A activates TNFR1 signaling through conserved IgG binding domains. J. Biol. Chem. 2006, 281, 20190-20196. [CrossRef]

60. Chavakis, T.; Wiechmann, K.; Preissner, K.T.; Herrmann, M. Staphylococcus aureus interactions with the endothelium: The role of bacterial "secretable expanded repertoire adhesive molecules" (SERAM) in disturbing host defense systems. Thromb. Haemost. 2005, 94, 278-285. [CrossRef]

61. Claes, J.; Vanassche, T.; Peetermans, M.; Liesenborghs, L.; Vandenbriele, C.; Vanhoorelbeke, K.; Missiakas, D.; Schneewind, O.; Hoylaerts, M.F.; Heying, R.; et al. Adhesion of Staphylococcus aureus to the vessel wall under flow is mediated by von Willebrand factor-binding protein. Blood 2014, 124, 1669-1676. [CrossRef]

62. Claes, J.; Liesenborghs, L.; Peetermans, M.; Veloso, T.R.; Missiakas, D.; Schneewind, O.; Mancini, S.; Entenza, J.M.; Hoylaerts, M.F.; Heying, R.; et al. Clumping factor A, von Willebrand factor-binding protein and von Willebrand factor anchor Staphylococcus aureus to the vessel wall. J. Thromb. Haemost. 2017, 15, 1009-1019. [CrossRef]

63. Bardoel, B.W.; Vos, R.; Bouman, T.; Aerts, P.C.; Bestebroer, J.; Huizinga, E.G.; Brondijk, T.H.; van Strijp, J.A.; de Haas, C.J. Evasion of Toll-like receptor 2 activation by staphylococcal superantigen-like protein 3. J. Mol. Med. (Berl.) 2012, 90, 1109-1120. [CrossRef]

64. Ibberson, C.B.; Jones, C.L.; Singh, S.; Wise, M.C.; Hart, M.E.; Zurawski, D.V.; Horswill, A.R. Staphylococcus aureus hyaluronidase is a CodY-regulated virulence factor. Infect. Immun. 2014, 82, 4253-4264. [CrossRef] [PubMed]

65. Kwiecinski, J.; Peetermans, M.; Liesenborghs, L.; Na, M.; Bjornsdottir, H.; Zhu, X.; Jacobsson, G.; Johansson, B.R.; Geoghegan, J.A.; Foster, T.J.; et al. Staphylokinase Control of Staphylococcus aureus Biofilm Formation and Detachment Through Host Plasminogen Activation. J. Infect. Dis. 2016, 213, 139-148. [CrossRef] [PubMed]

66. Fraser, J.D. Clarifying the mechanism of superantigen toxicity. PLoS Biol. 2011, 9, e1001145. [CrossRef] [PubMed]

67. McCormick, J.K.; Yarwood, J.M.; Schlievert, P.M. Toxic shock syndrome and bacterial superantigens: An update. Annu. Rev. Microbiol. 2001, 55, 77-104. [CrossRef] [PubMed]

68. Marrack, P.; Blackman, M.; Kushnir, E.; Kappler, J. The toxicity of staphylococcal enterotoxin B in mice is mediated by T cells. J. Exp. Med. 1990, 171, 455-464. [CrossRef] [PubMed]

69. Kaempfer, R.; Arad, G.; Levy, R.; Hillman, D.; Nasie, I.; Rotfogel, Z. CD28: Direct and critical receptor for superantigen toxins. Toxins (Basel) 2013, 5, 1531-1542. [CrossRef] [PubMed]

70. Gouaux, E. alpha-Hemolysin from Staphylococcus aureus: An archetype of beta-barrel, channel-forming toxins. J. Struct. Biol. 1998, 121, 110-122. [CrossRef]

71. Krieg, A.M.; Yi, A.K.; Matson, S.; Waldschmidt, T.J.; Bishop, G.A.; Teasdale, R.; Koretzky, G.A.; Klinman, D.M. CpG motifs in bacterial DNA trigger direct B-cell activation. Nature 1995, 374, 546-549. [CrossRef] 
72. Deng, G.M.; Liu, Z.Q.; Tarkowski, A. Intracisternally localized bacterial DNA containing CpG motifs induces meningitis. J. Immunol. 2001, 167, 4616-4626. [CrossRef]

73. Ali, A.; Zhu, X.; Kwiecinski, J.; Gjertsson, I.; Lindholm, C.; Iwakura, Y.; Wang, X.; Lycke, N.; Josefsson, E.; Pullerits, R.; et al. Antibiotic-killed Staphylococcus aureus induces destructive arthritis in mice. Arthritis Rheumatol. 2015, 67, 107-116. [CrossRef]

74. Verdrengh, M.; Tarkowski, A. Role of neutrophils in experimental septicemia and septic arthritis induced by Staphylococcus aureus. Infect. Immun. 1997, 65, 2517-2521. [CrossRef] [PubMed]

75. Verdrengh, M.; Tarkowski, A. Role of macrophages in Staphylococcus aureus-induced arthritis and sepsis. Arthritis Rheum. 2000, 43, 2276-2282. [CrossRef]

76. Nilsson, N.; Bremell, T.; Tarkowski, A.; Carlsten, H. Protective role of NK1.1+ cells in experimental Staphylococcus aureus arthritis. Clin. Exp. Immunol. 1999, 117, 63-69. [CrossRef] [PubMed]

77. Krishack, P.A.; Louviere, T.J.; Decker, T.S.; Kuzel, T.G.; Greenberg, J.A.; Camacho, D.F.; Hrusch, C.L.; Sperling, A.I.; Verhoef, P.A. Protection against Staphylococcus aureus bacteremia-induced mortality depends on ILC2s and eosinophils. JCI Insight 2019, 4. [CrossRef] [PubMed]

78. Abdelnour, A.; Bremell, T.; Holmdahl, R.; Tarkowski, A. Role of T lymphocytes in experimental Staphylococcus aureus arthritis. Scand. J. Immunol. 1994, 39, 403-408. [CrossRef]

79. Bergmann, B.; Fei, Y.; Jirholt, P.; Hu, Z.; Bergquist, M.; Ali, A.; Lindholm, C.; Ekwall, O.; Churlaud, G.; Klatzmann, D.; et al. Pre-treatment with IL2 gene therapy alleviates Staphylococcus aureus arthritis in mice. BMC Infect. Dis. 2020, 20, 185. [CrossRef]

80. Gjertsson, I.; Hultgren, O.H.; Stenson, M.; Holmdahl, R.; Tarkowski, A. Are B lymphocytes of importance in severe Staphylococcus aureus infections? Infect. Immun. 2000, 68, 2431-2434. [CrossRef]

81. Wuescher, L.M.; Takashima, A.; Worth, R.G. A novel conditional platelet depletion mouse model reveals the importance of platelets in protection against Staphylococcus aureus bacteremia. J. Thromb. Haemost. 2015, 13, 303-313. [CrossRef]

82. Piliponsky, A.M.; Shubin, N.J.; Lahiri, A.K.; Truong, P.; Clauson, M.; Niino, K.; Tsuha, A.L.; Nedospasov, S.A.; Karasuyama, H.; Reber, L.L.; et al. Basophil-derived tumor necrosis factor can enhance survival in a sepsis model in mice. Nat. Immunol. 2019, 20, 129-140. [CrossRef]

83. Akira, S.; Uematsu, S.; Takeuchi, O. Pathogen recognition and innate immunity. Cell 2006, 124, 783-801. [CrossRef]

84. Kolaczkowska, E.; Kubes, P. Neutrophil recruitment and function in health and inflammation. Nat. Rev. Immunol. 2013, 13, 159-175. [CrossRef] [PubMed]

85. Abbas, A.K.; Lichtman, A.H. Basic Immunology: Functions and Disorders of the Immune System, 3rd ed.; Saunders/Elsevier: Philadelphia, PA, USA, 2009.

86. Yipp, B.G.; Petri, B.; Salina, D.; Jenne, C.N.; Scott, B.N.; Zbytnuik, L.D.; Pittman, K.; Asaduzzaman, M.; Wu, K.; Meijndert, H.C.; et al. Infection-induced NETosis is a dynamic process involving neutrophil multitasking in vivo. Nat. Med. 2012, 18, 1386-1393. [CrossRef] [PubMed]

87. Molne, L.; Verdrengh, M.; Tarkowski, A. Role of neutrophil leukocytes in cutaneous infection caused by Staphylococcus aureus. Infect. Immun. 2000, 68, 6162-6167. [CrossRef] [PubMed]

88. Mills, C.D. Anatomy of a discovery: $\mathrm{m} 1$ and $\mathrm{m} 2$ macrophages. Front. Immunol. 2015, 6, 212. [CrossRef]

89. Rath, M.; Muller, I.; Kropf, P.; Closs, E.I.; Munder, M. Metabolism via Arginase or Nitric Oxide Synthase: Two Competing Arginine Pathways in Macrophages. Front. Immunol. 2014, 5, 532. [CrossRef]

90. Mosser, D.M.; Edwards, J.P. Exploring the full spectrum of macrophage activation. Nat. Rev. Immunol. 2008, 8, 958-969. [CrossRef]

91. Makita, N.; Hizukuri, Y.; Yamashiro, K.; Murakawa, M.; Hayashi, Y. IL-10 enhances the phenotype of M2 macrophages induced by IL-4 and confers the ability to increase eosinophil migration. Int. Immunol. 2015, 27, 131-141. [CrossRef]

92. Dey, A.; Allen, J.; Hankey-Giblin, P.A. Ontogeny and polarization of macrophages in inflammation: Blood monocytes versus tissue macrophages. Front. Immunol. 2014, 5, 683. [CrossRef]

93. Tanaka, Y.; Nakayamada, S.; Okada, Y. Osteoblasts and osteoclasts in bone remodeling and inflammation. Curr. Drug Targets Inflamm. Allergy 2005, 4, 325-328. [CrossRef]

94. Ogata, Y.; Kukita, A.; Kukita, T.; Komine, M.; Miyahara, A.; Miyazaki, S.; Kohashi, O. A novel role of IL-15 in the development of osteoclasts: Inability to replace its activity with IL-2. J. Immunol. 1999, 162, 2754-2760.

95. Djaafar, S.; Pierroz, D.D.; Chicheportiche, R.; Zheng, X.X.; Ferrari, S.L.; Ferrari-Lacraz, S. Inhibition of T cell-dependent and RANKL-dependent osteoclastogenic processes associated with high levels of bone mass in interleukin-15 receptor-deficient mice. Arthritis Rheum. 2010, 62, 3300-3310. [CrossRef] [PubMed]

96. Henningsson, L.; Jirholt, P.; Bogestal, Y.R.; Eneljung, T.; Adiels, M.; Lindholm, C.; McInnes, I.; Bulfone-Paus, S.; Lerner, U.H.; Gjertsson, I. Interleukin 15 mediates joint destruction in Staphylococcus aureus arthritis. J. Infect. Dis. 2012, 206, 687-696. [CrossRef] [PubMed]

97. Verdrengh, M.; Bokarewa, M.; Ohlsson, C.; Stolina, M.; Tarkowski, A. RANKL-targeted therapy inhibits bone resorption in experimental Staphylococcus aureus-induced arthritis. Bone 2010, 46, 752-758. [CrossRef] [PubMed]

98. Deng, G.M.; Verdrengh, M.; Liu, Z.Q.; Tarkowski, A. The major role of macrophages and their product tumor necrosis factor alpha in the induction of arthritis triggered by bacterial DNA containing CpG motifs. Arthritis Rheum. 2000, 43, 2283-2289. [CrossRef]

99. Small, C.L.; McCormick, S.; Gill, N.; Kugathasan, K.; Santosuosso, M.; Donaldson, N.; Heinrichs, D.E.; Ashkar, A.; Xing, Z. NK cells play a critical protective role in host defense against acute extracellular Staphylococcus aureus bacterial infection in the lung. J. Immunol. 2008, 180, 5558-5568. [CrossRef] 
100. Laarman, A.J.; Ruyken, M.; Malone, C.L.; van Strijp, J.A.; Horswill, A.R.; Rooijakkers, S.H. Staphylococcus aureus metalloprotease aureolysin cleaves complement C3 to mediate immune evasion. J. Immunol. 2011, 186, 6445-6453. [CrossRef]

101. Laarman, A.; Milder, F.; van Strijp, J.; Rooijakkers, S. Complement inhibition by gram-positive pathogens: Molecular mechanisms and therapeutic implications. J. Mol. Med. (Berl.) 2010, 88, 115-120. [CrossRef]

102. Sakiniene, E.; Bremell, T.; Tarkowski, A. Complement depletion aggravates Staphylococcus aureus septicaemia and septic arthritis. Clin. Exp. Immunol. 1999, 115, 95-102. [CrossRef]

103. Na, M.; Jarneborn, A.; Ali, A.; Welin, A.; Magnusson, M.; Stokowska, A.; Pekna, M.; Jin, T. Deficiency of the complement component 3 but not factor B aggravates Staphylococcus aureus septic arthritis in mice. Infect. Immun. 2016. [CrossRef]

104. Andersen, M.H.; Schrama, D.; Thor Straten, P.; Becker, J.C. Cytotoxic T cells. J. Investig. Dermatol. 2006, 126, 32-41. [CrossRef]

105. Sakaguchi, S.; Yamaguchi, T.; Nomura, T.; Ono, M. Regulatory T cells and immune tolerance. Cell 2008, 133, 775-787. [CrossRef] [PubMed]

106. Tesmer, L.A.; Lundy, S.K.; Sarkar, S.; Fox, D.A. Th17 cells in human disease. Immunol. Rev. 2008, 223, 87-113. [CrossRef] [PubMed]

107. Kidd, P. Th1/Th2 balance: The hypothesis, its limitations, and implications for health and disease. Altern. Med. Rev. 2003, 8 , 223-246. [PubMed]

108. Romagnani, S. Th1/Th2 cells. Inflamm. Bowel Dis. 1999, 5, 285-294. [CrossRef] [PubMed]

109. Oosterwegel, M.A.; Mandelbrot, D.A.; Boyd, S.D.; Lorsbach, R.B.; Jarrett, D.Y.; Abbas, A.K.; Sharpe, A.H. The role of CTLA-4 in regulating Th2 differentiation. J. Immunol. 1999, 163, 2634-2639. [PubMed]

110. Ali, A.; Welin, A.; Schwarze, J.C.; Svensson, M.N.; Na, M.; Jarneborn, A.; Magnusson, M.; Mohammad, M.; Kwiecinski, J.; Josefsson, E.; et al. CTLA4 Immunoglobulin but Not Anti-Tumor Necrosis Factor Therapy Promotes Staphylococcal Septic Arthritis in Mice. J. Infect. Dis. 2015, 212, 1308-1316. [CrossRef]

111. Parker, D.; Ryan, C.L.; Alonzo, F., 3rd; Torres, V.J.; Planet, P.J.; Prince, A.S. CD4+ T cells promote the pathogenesis of Staphylococcus aureus pneumonia. J. Infect. Dis. 2015, 211, 835-845. [CrossRef]

112. Jin, T.; Mohammad, M.; Hu, Z.; Fei, Y.; Moore, E.R.B.; Pullerits, R.; Ali, A. A novel mouse model for septic arthritis induced by Pseudomonas aeruginosa. Sci. Rep. 2019, 9, 16868. [CrossRef]

113. Cho, J.S.; Pietras, E.M.; Garcia, N.C.; Ramos, R.I.; Farzam, D.M.; Monroe, H.R.; Magorien, J.E.; Blauvelt, A.; Kolls, J.K.; Cheung, A.L.; et al. IL-17 is essential for host defense against cutaneous Staphylococcus aureus infection in mice. J. Clin. Investig. 2010, 120, 1762-1773. [CrossRef]

114. Henningsson, L.; Jirholt, P.; Lindholm, C.; Eneljung, T.; Silverpil, E.; Iwakura, Y.; Linden, A.; Gjertsson, I. Interleukin-17A during local and systemic Staphylococcus aureus-induced arthritis in mice. Infect. Immun. 2010, 78, 3783-3790. [CrossRef]

115. Kwiecinski, J.; Rhost, S.; Lofbom, L.; Blomqvist, M.; Mansson, J.E.; Cardell, S.L.; Jin, T. Sulfatide attenuates experimental Staphylococcus aureus sepsis through a CD1d-dependent pathway. Infect. Immun. 2013, 81, 1114-1120. [CrossRef]

116. Sonnenberg, G.F.; Hepworth, M.R. Functional interactions between innate lymphoid cells and adaptive immunity. Nat. Rev. Immunol. 2019, 19, 599-613. [CrossRef]

117. Ali, R.A.; Wuescher, L.M.; Dona, K.R.; Worth, R.G. Platelets Mediate Host Defense against Staphylococcus aureus through Direct Bactericidal Activity and by Enhancing Macrophage Activities. J. Immunol. 2017, 198, 344-351. [CrossRef]

118. Hultgren, O.; Eugster, H.P.; Sedgwick, J.D.; Korner, H.; Tarkowski, A. TNF/lymphotoxin-alpha double-mutant mice resist septic arthritis but display increased mortality in response to Staphylococcus aureus. J. Immunol. 1998, 161, 5937-5942.

119. Hultgren, O.H.; Svensson, L.; Tarkowski, A. Critical role of signaling through IL-1 receptor for development of arthritis and sepsis during Staphylococcus aureus infection. J. Immunol. 2002, 168, 5207-5212. [CrossRef]

120. Lenski, M.; Scherer, M.A. The significance of interleukin-6 and lactate in the synovial fluid for diagnosing native septic arthritis. Acta Orthop. Belg. 2014, 80, 18-25.

121. Hultgren, O.H.; Stenson, M.; Tarkowski, A. Role of IL-12 in Staphylococcus aureus-triggered arthritis and sepsis. Arthritis Res. 2001, 3, 41-47. [CrossRef]

122. Hultgren, O.; Kopf, M.; Tarkowski, A. Staphylococcus aureus-induced septic arthritis and septic death is decreased in IL-4deficient mice: Role of IL-4 as promoter for bacterial growth. J. Immunol. 1998, 160, 5082-5087.

123. Hultgren, O.; Kopf, M.; Tarkowski, A. Outcome of Staphylococcus aureus-triggered sepsis and arthritis in IL-4-deficient mice depends on the genetic background of the host. Eur. J. Immunol. 1999, 29, 2400-2405. [CrossRef]

124. Gjertsson, I.; Hultgren, O.H.; Tarkowski, A. Interleukin-10 ameliorates the outcome of Staphylococcus aureus arthritis by promoting bacterial clearance. Clin. Exp. Immunol. 2002, 130, 409-414. [CrossRef]

125. Zhao, Y.X.; Nilsson, I.M.; Tarkowski, A. The dual role of interferon-gamma in experimental Staphylococcus aureus septicaemia versus arthritis. Immunology 1998, 93, 80-85. [CrossRef]

126. Jarneborn, A.; Mohammad, M.; Engdahl, C.; Hu, Z.; Na, M.; Ali, A.; Jin, T. Tofacitinib treatment aggravates Staphylococcus aureus septic arthritis, but attenuates sepsis and enterotoxin induced shock in mice. Sci. Rep. 2020, 10, 10891. [CrossRef]

127. Davis, L.S.; Hutcheson, J.; Mohan, C. The role of cytokines in the pathogenesis and treatment of systemic lupus erythematosus. J. Interferon Cytokine Res. 2011, 31, 781-789. [CrossRef]

128. Osiri, M.; Ruxrungtham, K.; Nookhai, S.; Ohmoto, Y.; Deesomchok, U. IL-1beta, IL-6 and TNF-alpha in synovial fluid of patients with non-gonococcal septic arthritis. Asian Pac. J. Allergy Immunol. 1998, 16, 155-160.

129. Na, M.; Wang, W.; Fei, Y.; Josefsson, E.; Ali, A.; Jin, T. Both anti-TNF and CTLA4 Ig treatments attenuate the disease severity of staphylococcal dermatitis in mice. PLoS ONE 2017, 12, e0173492. [CrossRef] 
130. Jacques, C.; Gosset, M.; Berenbaum, F.; Gabay, C. The role of IL-1 and IL-1Ra in joint inflammation and cartilage degradation. Vitam. Horm. 2006, 74, 371-403. [CrossRef]

131. Dinarello, C.A. Interleukin-1 in the pathogenesis and treatment of inflammatory diseases. Blood 2011, 117, 3720-3732. [CrossRef]

132. Zhao, Y.X.; Tarkowski, A. Impact of interferon-gamma receptor deficiency on experimental Staphylococcus aureus septicemia and arthritis. J. Immunol. 1995, 155, 5736-5742.

133. O'Garra, A. Cytokines induce the development of functionally heterogeneous T helper cell subsets. Immunity 1998, 8, 275-283. [CrossRef]

134. Scheller, J.; Chalaris, A.; Schmidt-Arras, D.; Rose-John, S. The pro- and anti-inflammatory properties of the cytokine interleukin-6. Biochim Biophys Acta 2011, 1813, 878-888. [CrossRef]

135. Ivanov, S.; Linden, A. Interleukin-17 as a drug target in human disease. Trends Pharmacol. Sci. 2009, 30, 95-103. [CrossRef] [PubMed]

136. Sharff, K.A.; Richards, E.P.; Townes, J.M. Clinical management of septic arthritis. Curr. Rheumatol. Rep. 2013, 15, 332. [CrossRef] [PubMed]

137. Tarkowski, A. Infection and musculoskeletal conditions: Infectious arthritis. Best Pract. Res. Clin. Rheumatol. 2006, 20, 1029-1044. [CrossRef]

138. Goldenberg, D.L. Septic arthritis. Lancet 1998, 351, 197-202. [CrossRef]

139. Garcia-Arias, M.; Balsa, A.; Mola, E.M. Septic arthritis. Best Pract. Res. Clin. Rheumatol. 2011, 25, 407-421. [CrossRef]

140. Mathews, C.J.; Weston, V.C.; Jones, A.; Field, M.; Coakley, G. Bacterial septic arthritis in adults. Lancet 2010, 375, 846-855. [CrossRef]

141. Morgan, D.S.; Fisher, D.; Merianos, A.; Currie, B.J. An 18 year clinical review of septic arthritis from tropical Australia. Epidemiol. Infect. 1996, 117, 423-428. [CrossRef]

142. Fowler, V.G., Jr.; Sanders, L.L.; Sexton, D.J.; Kong, L.; Marr, K.A.; Gopal, A.K.; Gottlieb, G.; McClelland, R.S.; Corey, G.R. Outcome of Staphylococcus aureus bacteremia according to compliance with recommendations of infectious diseases specialists: Experience with 244 patients. Clin. Infect. Dis. 1998, 27, 478-486. [CrossRef]

143. Marr, K.A.; Kong, L.; Fowler, V.G.; Gopal, A.; Sexton, D.J.; Conlon, P.J.; Corey, G.R. Incidence and outcome of Staphylococcus aureus bacteremia in hemodialysis patients. Kidney Int. 1998, 54, 1684-1689. [CrossRef]

144. Naber, C.K. Staphylococcus aureus bacteremia: Epidemiology, pathophysiology, and management strategies. Clin. Infect. Dis. 2009, 48 (Suppl. 4), S231-S237. [CrossRef]

145. Holland, T.L.; Arnold, C.; Fowler, V.G., Jr. Clinical management of Staphylococcus aureus bacteremia: A review. JAMA 2014, 312, 1330-1341. [CrossRef] [PubMed]

146. Martin, G.S. Sepsis, severe sepsis and septic shock: Changes in incidence, pathogens and outcomes. Expert. Rev. Anti Infect. Ther. 2012, 10, 701-706. [CrossRef] [PubMed]

147. Van Amersfoort, E.S.; Van Berkel, T.J.; Kuiper, J. Receptors, mediators, and mechanisms involved in bacterial sepsis and septic shock. Clin. Microbiol. Rev. 2003, 16, 379-414. [CrossRef] [PubMed]

148. Huttunen, R.; Aittoniemi, J. New concepts in the pathogenesis, diagnosis and treatment of bacteremia and sepsis. J. Infect. 2011, 63, 407-419. [CrossRef] [PubMed]

149. Semeraro, N.; Ammollo, C.T.; Semeraro, F.; Colucci, M. Sepsis-associated disseminated intravascular coagulation and thromboembolic disease. Mediterr. J. Hematol. Infect. Dis. 2010, 2, e2010024. [CrossRef] [PubMed]

150. Romling, U.; Balsalobre, C. Biofilm infections, their resilience to therapy and innovative treatment strategies. J. Intern. Med. 2012, 272, 541-561. [CrossRef] [PubMed]

151. Stoodley, P.; Nistico, L.; Johnson, S.; Lasko, L.A.; Baratz, M.; Gahlot, V.; Ehrlich, G.D.; Kathju, S. Direct demonstration of viable Staphylococcus aureus biofilms in an infected total joInt. arthroplasty. A case report. J. Bone Joint Surg. Am. 2008, 90, 1751-1758. [CrossRef]

152. Dastgheyb, S.; Parvizi, J.; Shapiro, I.M.; Hickok, N.J.; Otto, M. Effect of biofilms on recalcitrance of staphylococcal joInt. infection to antibiotic treatment. J. Infect. Dis. 2015, 211, 641-650. [CrossRef]

153. Davies, D. Understanding biofilm resistance to antibacterial agents. Nat. Rev. Drug Discov. 2003, 2, 114-122. [CrossRef]

154. Patti, J.M.; Allen, B.L.; McGavin, M.J.; Hook, M. MSCRAMM-mediated adherence of microorganisms to host tissues. Annu. Rev. Microbiol. 1994, 48, 585-617. [CrossRef]

155. Kwiecinski, J.; Kahlmeter, G.; Jin, T. Biofilm formation by Staphylococcus aureus isolates from skin and soft tissue infections. Curr. Microbiol. 2015, 70, 698-703. [CrossRef] [PubMed]

156. Otto, M. Staphylococcal infections: Mechanisms of biofilm maturation and detachment as critical determinants of pathogenicity. Annu. Rev. Med. 2013, 64, 175-188. [CrossRef] [PubMed]

157. Kwiecinski, J.; Na, M.; Jarneborn, A.; Jacobsson, G.; Peetermans, M.; Verhamme, P.; Jin, T. Tissue Plasminogen Activator Coating on Implant Surfaces Reduces Staphylococcus aureus Biofilm Formation. Appl. Environ. Microbiol. 2015, 82, 394-401. [CrossRef] [PubMed]

158. Lynch, S.V.; Pedersen, O. The Human Intestinal Microbiome in Health and Disease. N. Engl. J. Med. 2016, 375, 2369-2379. [CrossRef] [PubMed] 
159. Theriot, C.M.; Koenigsknecht, M.J.; Carlson, P.E., Jr.; Hatton, G.E.; Nelson, A.M.; Li, B.; Huffnagle, G.B.; Li, Z.J.; Young, V.B. Antibiotic-induced shifts in the mouse gut microbiome and metabolome increase susceptibility to Clostridium difficile infection. Nat. Commun. 2014, 5, 3114. [CrossRef]

160. Libertucci, J.; Young, V.B. The role of the microbiota in infectious diseases. Nat. Microbiol. 2019, 4, 35-45. [CrossRef]

161. Sewankambo, N.; Gray, R.H.; Wawer, M.J.; Paxton, L.; McNaim, D.; Wabwire-Mangen, F.; Serwadda, D.; Li, C.; Kiwanuka, N.; Hillier, S.L.; et al. HIV-1 infection associated with abnormal vaginal flora morphology and bacterial vaginosis. Lancet 1997, 350, 546-550. [CrossRef]

162. Hyoju, S.K.; Zaborin, A.; Keskey, R.; Sharma, A.; Arnold, W.; van den Berg, F.; Kim, S.M.; Gottel, N.; Bethel, C.; Charnot-Katsikas, A.; et al. Mice Fed an Obesogenic Western Diet, Administered Antibiotics, and Subjected to a Sterile Surgical Procedure Develop Lethal Septicemia with Multidrug-Resistant Pathobionts. mBio 2019, 10. [CrossRef]

163. Prescott, H.C.; Dickson, R.P.; Rogers, M.A.; Langa, K.M.; Iwashyna, T.J. Hospitalization Type and Subsequent Severe Sepsis. Am. J. Respir. Crit. Care Med. 2015, 192, 581-588. [CrossRef]

164. Taur, Y.; Xavier, J.B.; Lipuma, L.; Ubeda, C.; Goldberg, J.; Gobourne, A.; Lee, Y.J.; Dubin, K.A.; Socci, N.D.; Viale, A.; et al. Intestinal domination and the risk of bacteremia in patients undergoing allogeneic hematopoietic stem cell transplantation. Clin. Infect. Dis. 2012, 55, 905-914. [CrossRef]

165. Wu, H.J.; Ivanov, I.I.; Darce, J.; Hattori, K.; Shima, T.; Umesaki, Y.; Littman, D.R.; Benoist, C.; Mathis, D. Gut-residing segmented filamentous bacteria drive autoimmune arthritis via T helper 17 cells. Immunity 2010, 32, 815-827. [CrossRef] [PubMed]

166. Jubair, W.K.; Hendrickson, J.D.; Severs, E.L.; Schulz, H.M.; Adhikari, S.; Ir, D.; Pagan, J.D.; Anthony, R.M.; Robertson, C.E.; Frank, D.N.; et al. Modulation of Inflammatory Arthritis in Mice by Gut Microbiota Through Mucosal Inflammation and Autoantibody Generation. Arthritis Rheumatol. 2018, 70, 1220-1233. [CrossRef]

167. Breban, M.; Tap, J.; Leboime, A.; Said-Nahal, R.; Langella, P.; Chiocchia, G.; Furet, J.P.; Sokol, H. Faecal microbiota study reveals specific dysbiosis in spondyloarthritis. Ann. Rheum. Dis. 2017, 76, 1614-1622. [CrossRef] [PubMed]

168. Ulici, V.; Kelley, K.L.; Azcarate-Peril, M.A.; Cleveland, R.J.; Sartor, R.B.; Schwartz, T.A.; Loeser, R.F. Osteoarthritis induced by destabilization of the medial meniscus is reduced in germ-free mice. Osteoarthr. Cartil. 2018, 26, 1098-1109. [CrossRef] [PubMed]

169. Henrotin, Y.; Patrier, S.; Pralus, A.; Roche, M.; Nivoliez, A. Protective Actions of Oral Administration of Bifidobacterium longum CBi0703 in Spontaneous Osteoarthritis in Dunkin Hartley Guinea Pig Model. Cartilage 2019, 1947603519841674. [CrossRef] [PubMed]

170. Rios, J.L.; Bomhof, M.R.; Reimer, R.A.; Hart, D.A.; Collins, K.H.; Herzog, W. Protective effect of prebiotic and exercise intervention on knee health in a rat model of diet-induced obesity. Sci. Rep. 2019, 9, 3893. [CrossRef] [PubMed]

171. Kaandorp, C.J.; Van Schaardenburg, D.; Krijnen, P.; Habbema, J.D.; van de Laar, M.A. Risk factors for septic arthritis in patients with joint disease. A prospective study. Arthritis Rheum. 1995, 38, 1819-1825. [CrossRef] [PubMed]

172. Walsh, N.C.; Gravallese, E.M. Bone remodeling in rheumatic disease: A question of balance. Immunol. Rev. 2010, $233,301-312$. [CrossRef]

173. Udagawa, N.; Takahashi, N.; Akatsu, T.; Tanaka, H.; Sasaki, T.; Nishihara, T.; Koga, T.; Martin, T.J.; Suda, T. Origin of osteoclasts: Mature monocytes and macrophages are capable of differentiating into osteoclasts under a suitable microenvironment prepared by bone marrow-derived stromal cells. Proc. Natl. Acad. Sci. USA 1990, 87, 7260-7264. [CrossRef]

174. Fei, Y.; Wang, W.; Kwiecinski, J.; Josefsson, E.; Pullerits, R.; Jonsson, I.M.; Magnusson, M.; Jin, T. The combination of a tumor necrosis factor inhibitor and antibiotic alleviates staphylococcal arthritis and sepsis in mice. J. Infect. Dis. 2011, 204, 348-357. [CrossRef]

175. Ali, A.; Na, M.; Svensson, M.N.; Magnusson, M.; Welin, A.; Schwarze, J.C.; Mohammad, M.; Josefsson, E.; Pullerits, R.; Jin, T. IL-1 Receptor Antagonist Treatment Aggravates Staphylococcal Septic Arthritis and Sepsis in Mice. PLoS ONE 2015, 10, e0131645. [CrossRef] [PubMed]

176. Tracey, K.J.; Fong, Y.; Hesse, D.G.; Manogue, K.R.; Lee, A.T.; Kuo, G.C.; Lowry, S.F.; Cerami, A. Anti-cachectin/TNF monoclonal antibodies prevent septic shock during lethal bacteraemia. Nature 1987, 330, 662-664. [CrossRef] [PubMed]

177. Okusawa, S.; Gelfand, J.A.; Ikejima, T.; Connolly, R.J.; Dinarello, C.A. Interleukin 1 induces a shock-like state in rabbits. Synergism with tumor necrosis factor and the effect of cyclooxygenase inhibition. J. Clin. Investig. 1988, 81, 1162-1172. [CrossRef]

178. Wang, H.; Bloom, O.; Zhang, M.; Vishnubhakat, J.M.; Ombrellino, M.; Che, J.; Frazier, A.; Yang, H.; Ivanova, S.; Borovikova, L.; et al. HMG-1 as a late mediator of endotoxin lethality in mice. Science 1999, 285, 248-251. [CrossRef] [PubMed]

179. Fisher, C.J., Jr.; Agosti, J.M.; Opal, S.M.; Lowry, S.F.; Balk, R.A.; Sadoff, J.C.; Abraham, E.; Schein, R.M.; Benjamin, E. Treatment of septic shock with the tumor necrosis factor receptor:Fc fusion protein. The Soluble TNF Receptor Sepsis Study Group. N. Engl. J. Med. 1996, 334, 1697-1702. [CrossRef]

180. Richter, A.; Listing, J.; Schneider, M.; Klopsch, T.; Kapelle, A.; Kaufmann, J.; Zink, A.; Strangfeld, A. Impact of treatment with biologic DMARDs on the risk of sepsis or mortality after serious infection in patients with rheumatoid arthritis. Ann. Rheum. Dis. 2016, 75, 1667-1673. [CrossRef] [PubMed]

181. Fattahi, F.; Ward, P.A. Understanding Immunosuppression after Sepsis. Immunity 2017, 47, 3-5. [CrossRef]

182. Lowy, F.D. Staphylococcus aureus infections. N. Engl. J. Med. 1998, 339, 520-532. [CrossRef]

183. Miller, L.S.; Fowler, V.G.; Shukla, S.K.; Rose, W.E.; Proctor, R.A. Development of a vaccine against Staphylococcus aureus invasive infections: Evidence based on human immunity, genetics and bacterial evasion mechanisms. FEMS Microbiol. Rev. 2020, 44, 123-153. [CrossRef] 
184. Smith, R.L.; Kajiyama, G.; Schurman, D.J. Staphylococcal septic arthritis: Antibiotic and nonsteroidal anti-inflammatory drug treatment in a rabbit model. J. Orthop. Res. 1997, 15, 919-926. [CrossRef]

185. Ferreira, C.R.; Xia, Z.J.; Clement, A.; Parry, D.A.; Davids, M.; Taylan, F.; Sharma, P.; Turgeon, C.T.; Blanco-Sanchez, B.; Ng, B.G.; et al. A Recurrent De Novo Heterozygous COG4 Substitution Leads to Saul-Wilson Syndrome, Disrupted Vesicular Trafficking, and Altered Proteoglycan Glycosylation. Am. J. Hum. Genet. 2018, 103, 553-567. [CrossRef] [PubMed]

186. Sakiniene, E.; Bremell, T.; Tarkowski, A. Addition of corticosteroids to antibiotic treatment ameliorates the course of experimental Staphylococcus aureus arthritis. Arthritis Rheum. 1996, 39, 1596-1605. [CrossRef] [PubMed]

187. Odio, C.M.; Ramirez, T.; Arias, G.; Abdelnour, A.; Hidalgo, I.; Herrera, M.L.; Bolanos, W.; Alpizar, J.; Alvarez, P. Double blind, randomized, placebo-controlled study of dexamethasone therapy for hematogenous septic arthritis in children. Pediatr. Infect. Dis. J. 2003, 22, 883-888. [CrossRef] [PubMed] 